\title{
Nutraceuticals in Periodontal Health: A Systematic Review on the Role of Vitamins in Periodontal Health Maintenance
}

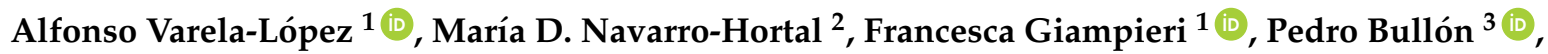 \\ Maurizio Battino ${ }^{1}$ (D) and José L. Quiles ${ }^{2, *(D)}$ \\ 1 Dipartimento di Scienze Cliniche Specialistiche ed Odontostomatologiche (DISCO)-Sez. Biochimica, \\ Facoltà di Medicina, Università Politecnica delle Marche, 60131 Ancona, Italy; \\ avarelalopez@gmail.com (A.V.-L.); f.giampieri@univpm.it (F.G.); m.a.battino@univpm.it (M.B.) \\ 2 Department of Physiology, Institute of Nutrition and Food Technology "Jose Mataix", \\ Biomedical Research Center, University of Granada, Avda. Conocimiento s/n, 18100 Armilla, Granada, \\ Spain; mdnavarrohortal@correo.ugr.es \\ 3 Department of Stomalogy, Dental School, University of Sevilla, C/Avicena s.n., 41009 Sevilla, Spain; \\ pbullon@us.es \\ * Correspondence: jlquiles@ugr.es; Tel.: +34-958241000 (ext. 20316)
}

Received: 25 April 2018; Accepted: 17 May 2018; Published: 20 May 2018

\begin{abstract}
Periodontal disease, a relevant public health problem worldwide, is generally considered a common pathology of elderly people. In this respect, there is agreement about that nutritional status may be a modifying factor in the progression and healing of the periodontal tissues. Vitamins have been recommended as nutraceuticals for prevention and treatment of some pathological conditions, such as cardiovascular diseases, obesity or cancer. Thus, a systematic approach to determining how the different vitamin type could ameliorate periodontal risks or improve periodontal health is necessary to further the understanding of the potential benefits and risks of vitamins supplementation use. For this, a systematic review of English-written literature in PubMed until February 2018, which included both human and animal research on the relationship of each vitamin with periodontal disease, was conducted. Among all the analyzed vitamins those with antioxidant capacity and effects on immune system seem to be useful for prevention or improvement of periodontal disease, as well as those implicated in bone metabolism. In the first case, there are quite information in favor of various vitamins, mainly vitamin $C$, that is the most studied. In the second case, vitamin D seems to have the most relevant role.
\end{abstract}

Keywords: diet; gingivitis; micronutrients; nutrition; oral health; periodontitis; supplementation

\section{Introduction}

Periodontal disease, a relevant public health problem worldwide, is generally considered a common pathology of elderly people [1]. In the United States (US), its prevalence is over $47 \%$, with $64 \%$ of adults aged 65 years and older having either moderate or severe periodontitis [2]. It is essentially a chronic inflammatory disease caused by specific oral microorganisms (e.g., Porphyromonas gingivalis and Aggregatibacter actinomycetemcomitans), characterized by the loss of supporting periodontal ligament and alveolar bone and is the first cause of tooth loss [3]. Periodontal disease is influenced by many risk factors, such as alcohol, stress, smoking, genetics, diabetes, and hormonal alteration status (i.e., pregnancy or menopause) [4], so that the maintenance of oral and periodontal health becomes today a challenge, especially considering that periodontal disease can be itself a risk factor for a number of chronic disorders. Indeed, it is generally accepted that periodontitis is strictly associated with many 
chronic diseases, such as type 2 diabetes mellitus (DM2), cardiovascular diseases, inflammatory bowel disease and rheumatoid arthritis [5]. Therefore, there is a growing interest in the relationship between oral health and systemic health.

Undoubtedly, oral microorganisms are indispensable for the pathogenesis of periodontal disease, but, among risk factors, nutrition represents an influential aspect that is often neglected [1]. Indeed, nutritional factors have a vital importance for the equilibrium between oral microorganisms and the host response, from which depends the onset and progression of periodontal disease [6,7]. In the past, health-focused dietary approaches have mostly focused in reducing the consumption of "undesirable" dietary components such as sodium, refined sugars, and saturated fats. However, attention on promoting the consumption of "curative nutrients" has been expanded. This perception of "food or nutrient as a medicament" has encouraged the search of a growing number of new substances categorized from dietary supplements to "nutraceuticals", with the aim of improving human health, making us fitter and more resilient to disease [8,9]. "Nutraceuticals" are a category of substances without a legal definition, often sold as dietary supplements or components of conventional foods [10]. Zeisel [11] defined nutraceuticals as dietary supplements that delivers a concentrated form of a biologically active component of food in a non-food matrix to enhance health. A dietary supplement is a product that is intended to supplement the diet that bears or contains one or more ingredients like, vitamin, mineral, an herb, an amino acid or a concentrate, metabolite, constituent, extract, or combinations of these.

Because the scientific characterization and commercial regulation of such substances vary from country to country $[8,11,12]$, their popularity imposes the medical and scientific community a constant revision of their therapeutic potentials. Nutritional status of the host has been widely recognized as a possible promoting factor in many inflammatory conditions such as periodontal diseases $[13,14]$. Actually, the consumption of specific foods or extracts of specific foods have been shown to have an effect on both the oral health and the general health of patients with periodontal disease $[6,7,15]$. Among dietary factors, those nutrients that exert antioxidant and immunomodulatory effects $[6,7,16,17]$ or are implicated in bone metabolism $[6,7,18]$ could be a promising candidate for the prevention or the management of periodontal diseases. Vitamins that have been recommended as nutraceuticals for prevention and treatment of some pathological conditions, such as cardiovascular diseases, obesity or cancer [6,19], could have an interesting role. In fact, they are susceptible to be delivered as tablets or added to foods and a $20-30 \%$ of Americans currently consume multivitamin supplements daily, indicating high public interest in the prevention of chronic diseases through a nutrition-based approach [19].

In this context, epidemiologic studies generally evaluate foods rather than specific bioactive food components and there is still a scarcity of reports describing any effects of dietetic interventions on periodontitis. Thus, a systematic approach to determining how the different types of vitamins could ameliorate periodontal risks or improve periodontal health is necessary to understand the potential benefits and risks of vitamins supplementation. The aim of this review is to analyze the main published data until February 2018 on the relationship between vitamins and the development and progression of periodontal disease both in humans and animals.

\section{Results and Discussion}

Our initial search detected 6055 publications. Title and abstract screening left 51 potential articles according to the inclusion and exclusion criteria. Full-text screening and reading led to a final number of 41 articles which were included in this this review. All vitamins, except vitamin $\mathrm{K}$, were represented in the selected literature, although several studies evaluate the effects of different vitamins role at the same time. The results from these studies concerning each vitamin, as well as their most relevant methodological aspects for the aim of this review, are presented and discussed in separated sections below. 
In general, evidence supporting certain grade of relationship of vitamins with periodontal health is reduced in many cases. Most of information is provided by observational studies, particularly cross-sectional studies, and many of them were performed in specific groups. These groups differed in age, disease or health condition making thus difficult to translate these findings to the overall population. In addition to that, few articles deepened on the mechanisms under the observed relationships. Among other reasons, this could be due to methodological approach of this review. However, there are other reasons inherent to studies investigating diet or nutrition role in a pathology or disease outcomes [14]. For instance, possible relationships reported between nutritional status and disease outcomes are usually non-linear and typically exhibit a threshold effect [19]. Likewise, the methodology used to obtain data about both, dietary intakes and nutritional status, leads to other problems. However, dietary intakes estimation methods are usually susceptible to memory errors and bias [14]. Likewise, nutritional status biomarkers are not meaningful for certain nutrients [20]. Unfortunately, it was also not uncommon that dietary supplements also were ignored or normalized with the same value for all subjects. Lastly, there is also a wide variability with respect to the evaluation of periodontal health in the selected studies. Concerning this, assessed outcomes included various clinical parameters obtaining in the oral examinations (probing pocket depth (PPD), clinical attachment loss (CAL), bleeding on probing (BOP)), but also different indexes (Russell's Periodontal Index (RPI), Community Periodontal Index (CPI) or Community Periodontal Index of Treatment Needs (CPITN), Periodontal Index (PI), or Gingival Index (GI)) as well as different disease definitions or classifications. Likewise, number and loss of teeth were taken into account, although these depend only partially due to periodontitis. Consequently, findings from the studies collected in this review have a complex interpretation. This makes difficult to draw conclusions about the role of the different vitamins in periodontal disease, particularly for those less studied.

\subsection{Vitamin D}

Vitamin $\mathrm{D}$ is an inclusive term for several forms of the hormone cholecalciferol whose biologically active form is 1,25-dihydroxycholecalciferol $(1,25(\mathrm{OH}) 2 \mathrm{D} 3)$ [21]. This vitamin is the second most represented nutrient among the observational studies selected in this review with a total of eight articles (Table 1). In detail, we found four cross-sectional, three case-control and two cohort studies. The best-known action of 1,25(OH)2D3 is regulation of plasma calcium and phosphorus levels affecting bone development and metabolism, but it is also essential for cell development and neuromuscular functioning [21,22]. In addition, vitamin D also has a role in the immune system and inflammation, inhibiting pro-inflammatory cytokines and T-lymphocyte proliferation, at least in vitro [23]. Actually, antigen-presenting cells, macrophages and lymphocytes express a nuclear receptor for vitamin D. Activities on both, bone and immune system, result interesting for periodontal disease prevention and management since they would be useful preserving alveolar bone and gingival tissue. In contrast with other vitamins, animals can endogenously produce vitamin $\mathrm{D}$ by conversion of 7-dehydrocholesterol found in the skin into pre-vitamin D after exposure to the sun [24]. Thus, sun exposure notably influences RDA [25]. For this reason, vitamin D status is best determined by the level of serum or plasma 25-hydroxyvitamin $\mathrm{D}(25(\mathrm{OH}) \mathrm{D})$, which reflects the total contribution from both dietary and endogenous sources. Here, most of selected observational studies assessed nutritional status for this nutrient by $25(\mathrm{OH}) \mathrm{D}$ levels in blood, although dietary intakes were estimated in two of the selected cross-sectional studies.

Most interesting results were provided by a 20 year longitudinal study in the U.S. known as the Health Professionals Follow-Up Study, where predicted 25(OH)D score was inversely and dose-dependently associated with self-reported tooth loss and periodontal disease [26]. However, participant ages ranged from 40 to 75 years old. This has been supported by a cross-sectional study conducted on a sample of 11,202 subjects participating in NHANES III reported an inverse association between serum $25(\mathrm{OH}) \mathrm{D}$ and CAL in men and women, but only in subjects over 50 years old in both genders [27]. In this sense, a cross-sectional study in a male relatively aged segment $(62.9 \pm$ 
7.6 years), but with a more reduced ample size $(\mathrm{N}=562)$ also suggest this an inverse association between vitamin D intake and severe periodontitis according to American Academy of Periodontology (AAP) criteria. A similar association was found for moderate-to severe ABL (i.e., $40 \%$ of ABL at three or more sites) calculated from conventional periapical radiographs [28]. These studies are in consistency with the previous study and, along with it, point out adults at middle or higher age as risk group where correct vitamin D intake could have a key role in periodontal health maintenance. Similarly, a case control study with a more reduced sample of periodontitis-affected and periodontally healthy subjects from Puerto Rico has reported a associations between serum levels of $25(\mathrm{OH}) \mathrm{D}$ and periodontal condition [29]. In contrast, no significant association was found in a cross-sectional study in a representative sample of Denmark [30]. Likewise in other cross-sectional study performed on participants in fourth Korea National Health and Nutrition Examination Survey (KNHANES) evaluating association between vitamin D deficiency, in this case determined by serum levels, and prevalence of periodontitis defined by a CPI of 3 or higher in 6011 individuals [31]. However, no association was observed. On the other hand, stratified analyses revealed a significant association in current smokers [31]. Absence of association in one of these studies could be due to periodontal health measure since CAL or CPI that is based in PPD and can under evaluate bone loss. Still, this last study suggest that vitamin D could be of important for periodontal health in smokers as occurred for other vitamins.

Combined results from all previous studies suggest that starting to take vitamin D supplementation from middle age could be particularly interesting for preventing periodontal disease advancement. This was expected given the role of vitamin D in bone metabolism as well as role of age as risk factor for bone health maintenance. In this sense, several studies have been performed on subgroups with conditions that represent a risk for bone health. In relation to age, two studies were only focused on postmenopausal women but reported association depending on parameter using to evaluate periodontal health or nutritional status. These included a cohort study [32] where no significant associations were found after a 5 year follow-up period with different parameters related to periodontal health. Included parameters were alveolar crestal height (ACH), CAL, PPD and \% BOP. Results did not confirm any association with $25(\mathrm{OH}) \mathrm{D}$ levels. In contrast, an inverse association was found in a cross-sectional study in which two definitions of periodontal disease, one based on $\mathrm{ACH}$ measures and tooth loss and the other based on CDC/AAP criteria, were used [33]. Likewise, acute oral inflammation was assessed by percentage of BOP and they found that $42 \%$ of same group showed lower odds of having $50 \%$ of gingival sites that bled or more. Lastly, pregnancy also has been taken into account in a case-control study. In this, women with clinically moderate to severe periodontal disease presented lower levels and higher prevalence of vitamin deficiency than periodontal healthy women [34]. According to these results, recommendations of vitamin D (and probably calcium)-supplements use for people under physiological or pathological conditions that increase the risk of suffers bone pathologies or pathological alterations, also could contribute to protect periodontal tissues.

Interestingly, in a case-control study that discriminated between patients with generalized aggressive periodontitis and chronic periodontitis, it was noted higher plasma calcifediol levels in patients with aggressive periodontitis compared with healthy controls, but not in chronic periodontitis cases [35]. Additionally, partial intra-groups correlations with main clinical outcomes (PPD, CAL, bleeding index, \% surfaces with BOP) were analyzed and it was found a positive association with $\mathrm{BI}$ in this group. Confounding could be explained by the differences among these studies. The first case-control did not evaluate possible confounding effects for skin color or sun exposure (while data collected over a 6 years period) that showed differences between groups when they were analyzed in the second case besides civil status, weight, medical insurance [34]. This could lead to underestimate towards null the associations with chronic periodontitis. On the other hand, aggressive periodontitis was not considered in the third investigation and it showed inverse relationships with vitamin D compared to more common periodontal disease or chronic periodontitis, although different etiology could be responsible. 
Table 1. Observational studies on vitamin $\mathrm{D}$ association with periodontal disease.

\begin{tabular}{|c|c|c|c|c|c|c|c|c|}
\hline $\begin{array}{l}\text { Study } \\
\text { Type }\end{array}$ & Sample & Sex; Age; N & $\begin{array}{l}\text { Dietary Intake } \\
\text { Assessment }\end{array}$ & $\begin{array}{l}\text { Nutritional } \\
\text { Status } \\
\text { Assessment }\end{array}$ & Periodonta Status & $\begin{array}{l}\text { Analysis Results } \\
(p \text {-Value })\end{array}$ & $\begin{array}{c}\text { Main } \\
\text { Results/Conclusions }\end{array}$ & Ref. \\
\hline \multirow{2}{*}{ CS } & \multirow{2}{*}{$\begin{array}{c}\text { DANHES 2007-2008 } \\
\text { participants (Denmark) }\end{array}$} & \multirow{2}{*}{$\begin{array}{l}\text { Both; } \geq 18 \mathrm{y} \\
\mathrm{N}=3287\end{array}$} & \multirow{2}{*}{$\begin{array}{l}\text { Vitamin D intake by } \\
\text { FFQ }\end{array}$} & \multirow[t]{2}{*}{ - } & $\begin{array}{c}\text { Severe } \\
\text { periodontitis }{ }^{1}\end{array}$ & N.S. (mult. logistic reg.) & \multirow{2}{*}{ No association } & \multirow{2}{*}{ [30] } \\
\hline & & & & & CAL & N.S. (mult. linear reg.) & & \\
\hline \multirow[b]{2}{*}{ CS } & \multirow{2}{*}{ DLS participants (USA) } & \multirow{2}{*}{$\begin{array}{c}\text { Male; } 62.9 \pm 7.6 \mathrm{y} \\
\quad \mathrm{N}=562\end{array}$} & \multirow{2}{*}{$\begin{array}{l}\text { Daily dietary intake } \\
\text { ( } \geq 400 \mathrm{IU}, 400-800 \mathrm{IU} \\
\text { or } \geq 800 \mathrm{IU} \text { ) by FFQ }\end{array}$} & \multirow[b]{2}{*}{-} & $\begin{array}{l}\text { Severe } \\
\text { periodontal } \\
\text { disease }^{1}\end{array}$ & $\begin{array}{c}\mathrm{OR}^{1}=0.67(95 \% \mathrm{CI}: \\
0.55-0.81) ; p<0.05 \text { for } \\
\text { trend (mult. logistic reg.) }\end{array}$ & \multirow{2}{*}{$\begin{array}{l}\text { Inverse } \\
\text { associations }\end{array}$} & \multirow[b]{2}{*}{ [28] } \\
\hline & & & & & $\begin{array}{l}\text { Moderate to } \\
\text { severe } \mathrm{ABL}^{2}\end{array}$ & $\begin{array}{c}\mathrm{OR}^{1}=0.54(95 \% \mathrm{CI}: \\
0.30-0.96) ; p<0.05 \text { for } \\
\text { trend (mult. logistic reg.) }\end{array}$ & & \\
\hline \multirow{5}{*}{ CS } & \multirow{5}{*}{$\begin{array}{l}\text { NHANES III participants } \\
\text { (USA) }\end{array}$} & \multirow{5}{*}{$\begin{array}{l}\text { Both; } \geq 20 y ; \\
N=11,202\end{array}$} & \multirow{5}{*}{-} & \multirow{5}{*}{$\begin{array}{l}\text { Serum levels of } \\
25(\mathrm{OH}) \mathrm{D} \\
\text { (quintile) }\end{array}$} & \multirow{4}{*}{ Mean CAL } & $\begin{array}{l}\text { N.S. (mult. linerar reg.) in } \\
\text { men <50 y old }\end{array}$ & \multirow{5}{*}{$\begin{array}{c}\text { Negative } \\
\text { association with } \\
\text { CAL, only in } \\
\text { subjects } \geq 50 \text { years }\end{array}$} & \multirow{5}{*}{ [27] } \\
\hline & & & & & & $\begin{array}{l}\mathrm{CAL}^{2}=+0.39 \mathrm{~mm}(95 \% \mathrm{CI}: \\
0.17-0.60) ; p=0.001 \text { (mult. } \\
\text { linerar reg.) in men } \\
\geq 50 \text { y old }\end{array}$ & & \\
\hline & & & & & & $\begin{array}{l}\text { N.S. (mult. linerar reg.) in } \\
\text { women }<50 \text { y old }\end{array}$ & & \\
\hline & & & & & & $\begin{array}{c}\mathrm{CAL}^{2}=+0.26 \mathrm{~mm}(95 \% \mathrm{CI}: \\
0.09-0.43) ; p=0.008 \text { (mult. } \\
\text { linerar reg.) in women } \\
\geq 50 \text { y old }\end{array}$ & & \\
\hline & & & & & $\% \mathrm{BOP}$ & $\begin{array}{l}\text { N.S. (mult. linerar reg.) in } \\
\text { all subsets }\end{array}$ & & \\
\hline \multirow{3}{*}{ CS } & \multirow{3}{*}{$\begin{array}{c}\text { 4th KNHANES } \\
\text { Participants (South Korea) }\end{array}$} & \multirow{3}{*}{$\begin{array}{l}\text { Both; } \geq 19 \mathrm{y} \\
\quad \mathrm{N}=6011\end{array}$} & \multirow{3}{*}{-} & \multirow{3}{*}{$\begin{array}{l}\text { Serum levels of } \\
25(\mathrm{OH}) \mathrm{D}(>20, \\
<20 \mathrm{ng} / \mathrm{mL}) \\
\text { deficiency }\end{array}$} & \multirow{3}{*}{$\mathrm{CPI} \geq 3$} & $\begin{array}{l}\text { N.S. (mult. logistic reg.) in } \\
\text { non-restricted model }\end{array}$ & \multirow{3}{*}{$\begin{array}{l}\text { Inverse } \\
\text { association only in } \\
\text { current smokers }\end{array}$} & \multirow{3}{*}{ [31] } \\
\hline & & & & & & $\begin{array}{l}\mathrm{OR}^{2}=1.53 \text { (95\%CI: } \\
1.07-2.18) \text { (mult. logistic } \\
\text { reg.) in model resticted to } \\
\text { current smokers }\end{array}$ & & \\
\hline & & & & & & $\begin{array}{l}\text { N.S. (mult. logistic reg.) in } \\
\text { model restricted to } \\
\text { non-current smokers }\end{array}$ & & \\
\hline
\end{tabular}


Table 1. Cont.

\begin{tabular}{|c|c|c|c|c|c|c|c|c|}
\hline $\begin{array}{l}\text { Study } \\
\text { Type }\end{array}$ & Sample & Sex; Age; N & $\begin{array}{l}\text { Dietary Intake } \\
\text { Assessment }\end{array}$ & $\begin{array}{l}\text { Nutritional } \\
\text { Status } \\
\text { Assessment }\end{array}$ & Periodonta Status & $\begin{array}{l}\text { Analysis Results } \\
(p \text {-Value })\end{array}$ & $\begin{array}{c}\text { Main } \\
\text { Results/Conclusions }\end{array}$ & Ref. \\
\hline \multirow{4}{*}{ CS } & \multirow{4}{*}{$\begin{array}{l}\text { Paticipants in OsteoPerio } \\
\text { Study (USA) }\end{array}$} & \multirow{4}{*}{$\begin{array}{c}\text { Female, } \\
\text { Postmenopause; } \\
\mathrm{N}=920\end{array}$} & \multirow{4}{*}{ - } & \multirow{4}{*}{$\begin{array}{l}\text { Plasma levels of } \\
25(\mathrm{OH}) \mathrm{D} \\
\text { (Adequate or } \\
\text { inadequate } \\
\text { nutritional status) }\end{array}$} & $50 \% \mathrm{BOP}$ & $\begin{array}{c}\mathrm{OR}=0.42 \%(95 \% \mathrm{CI}: \\
21-58 \%) ; p<0.05 \text { for } \\
\text { trend }\end{array}$ & \multirow{4}{*}{$\begin{array}{c}\text { Inverse } \\
\text { association with \% } \\
\text { BOP \& } \\
\text { periodontal } \\
\text { disease according } \\
\text { to CDC/AAP } \\
\text { criteria }{ }^{5}\end{array}$} & \multirow{4}{*}[33]{} \\
\hline & & & & & $\begin{array}{c}\text { periodontal } \\
\text { disease based on } \\
\text { ACH measures }^{3}\end{array}$ & N.S. & & \\
\hline & & & & & $\begin{array}{l}\text { periodontal } \\
\text { disease based on } \\
\text { CDC/AAP } \\
\text { criteria }^{1} \\
\end{array}$ & $\begin{array}{c}\mathrm{OR}=33 \%(95 \% \mathrm{CI} \\
5-53 \%) p<0.05 \text { for trend }\end{array}$ & & \\
\hline & & & & & tooth loss & N.S. & & \\
\hline $\mathrm{CC}$ & $\begin{array}{c}\text { Subjects from an } \\
\text { University Health Center } \\
\text { (China) }\end{array}$ & $\begin{array}{l}\text { Both; } 16-64 \text { y; } \\
\quad \mathrm{N}=178\end{array}$ & - & $\begin{array}{l}\text { Plasma levels of } \\
\text { 25(OH)D }\end{array}$ & $\begin{array}{c}\text { Aggressive } \\
\text { periodontitis }{ }^{4} \text { vs. } \\
\text { chronic } \\
\text { periodontitis-affected } \\
{ }^{4} \text { vs. healthy } \\
\text { (Staff) }\end{array}$ & $\begin{array}{l}29.28 \text { in aggressive } \\
\text { periodontitis patients } \\
>21.60 \mathrm{nmol} / \mathrm{L} \text { in } \\
\text { controls; } p<0.05 \\
\text { (ANCOVA) }\end{array}$ & $\begin{array}{l}\text { Plasma } 25(\mathrm{OH}) \mathrm{D} \\
\text { levels in patients } \\
\text { with aggressive } \\
\text { periodontitis were } \\
\text { higher than those } \\
\text { of healthy controls }\end{array}$ & [35] \\
\hline \multirow[b]{2}{*}{$\mathrm{CC}$} & \multirow[b]{2}{*}{$\begin{array}{l}\text { Women with a singleton } \\
\text { pregnancy taking vitamin } \\
\text { D supplements (USA) }\end{array}$} & \multirow[b]{2}{*}{$\begin{array}{l}27 \pm 6 \text { for } \\
\text { cases } / 31 \pm 6 \text { y for } \\
\text { controls; } \mathrm{N}=235\end{array}$} & & $\begin{array}{l}\text { Serum levels of } \\
\text { 25(OH)D }\end{array}$ & \multirow[b]{2}{*}{$\begin{array}{l}\text { Clinical moderate } \\
\text { to severe } \\
\text { periodontal } \\
\text { disease-affected }{ }^{5} \\
\text { vs. healthy }\end{array}$} & $\begin{array}{c}59>100 \mathrm{nmol} / \mathrm{L} ; \\
p<0.001 \text { (Wilcoxon } \\
\text { Mann-Whitney } \mathrm{U} \text { ) }\end{array}$ & \multirow[b]{2}{*}{$\begin{array}{c}\text { Subject with } \\
\text { periodontal } \\
\text { disease had lower } \\
\text { serum levels of } \\
\text { 25(OH)D }\end{array}$} & \multirow[b]{2}{*}{ [34] } \\
\hline & & & - & $\begin{array}{l}\text { Women with } \\
\text { vitamin D } \\
\text { deficiency } \\
(<75 \mathrm{nmol} / \mathrm{L})\end{array}$ & & $\begin{array}{l}65>29 \% ; p<0.001)\left(x^{2}\right. \\
\text { Test). Moreover, } \\
\text { multivariable analysis } \\
\text { showed an adjusted OR } \\
\text { of } 2.1 \text { between } \\
\text { periodontal disease and } \\
\text { vitamin D insufficiency } \\
(95 \% \text { CI. } 0.99-4.5)\end{array}$ & & \\
\hline
\end{tabular}


Table 1. Cont.

\begin{tabular}{|c|c|c|c|c|c|c|c|c|}
\hline $\begin{array}{l}\text { Study } \\
\text { Type }\end{array}$ & Sample & Sex; Age; N & $\begin{array}{l}\text { Dietary Intake } \\
\text { Assessment }\end{array}$ & $\begin{array}{l}\text { Nutritional } \\
\text { Status } \\
\text { Assessment }\end{array}$ & Periodonta Status & $\begin{array}{l}\text { Analysis Results } \\
(p \text {-Value })\end{array}$ & $\begin{array}{c}\text { Main } \\
\text { Results/Conclusions }\end{array}$ & Ref. \\
\hline \multirow{2}{*}{$\mathrm{CC}$} & \multirow{2}{*}{$\begin{array}{c}\text { Cases of moderate/severe } \\
\text { periodontitis \& } \\
\text { periodontally healthy } \\
\text { controls aged. (Puerto } \\
\text { Rico, USA) }\end{array}$} & \multirow{2}{*}{$\begin{array}{l}\text { Both; 35-64 y; } \\
\quad \mathrm{N}=38\end{array}$} & \multirow{2}{*}{-} & $\begin{array}{l}\text { Serum levels of } 25 \\
(\mathrm{OH}) \text { D levels }\end{array}$ & \multirow{2}{*}{$\begin{array}{l}\text { periodontal } \\
\text { disease }\end{array}$} & $\begin{array}{c}18.5( \pm 4.6) \mathrm{ng} / \mathrm{mL}< \\
24.2( \pm 7.1) \mathrm{ng} / \mathrm{mL} \\
p=0.006 .\end{array}$ & \multirow{2}{*}{$\begin{array}{l}\text { Inverse } \\
\text { association }\end{array}$} & \multirow{2}{*}{ [29] } \\
\hline & & & & $\begin{array}{l}\text { Serum levels of } 25 \\
(\mathrm{OH}) \text { D levels }\end{array}$ & & $\begin{array}{c}\mathrm{OR}=0.885(95 \% \mathrm{CI}: \\
0.785-0.997) p<0.05 \\
\text { for trend }\end{array}$ & & \\
\hline \multirow{4}{*}{ C (5 y) } & \multirow{4}{*}{$\begin{array}{c}\text { Postmenopausal } \\
\text { paticipants in OsteoPerio } \\
\text { Study (USA) }\end{array}$} & \multirow{4}{*}{$\begin{array}{c}\text { Female; } \\
\text { Postmenopause; } \\
\mathrm{N}=665\end{array}$} & \multirow{4}{*}{ - } & \multirow{4}{*}{$\begin{array}{l}\text { Plasma levels of } \\
25(\mathrm{OH}) \mathrm{D}\end{array}$} & $\begin{array}{c}\text { Mean ACH } \\
\text { increase }(1 \mathrm{~mm})\end{array}$ & N.S. (mult. linear reg.) & \multirow{4}{*}{ No association } & \multirow{4}{*}{ [32] } \\
\hline & & & & & $\begin{array}{c}\text { Mean CAL } \\
\text { increase }(1 \mathrm{~mm})\end{array}$ & N.S. (mult. linear reg.) & & \\
\hline & & & & & $\begin{array}{c}\text { Mean PD increase } \\
(1 \mathrm{~mm})\end{array}$ & N.S. (mult. linear reg.) & & \\
\hline & & & & & $\begin{array}{l}\text { Mean \% BOP } \\
\text { increase (1\%) }\end{array}$ & N.S. (mult. linear reg.). & & \\
\hline \multirow{2}{*}{$C(20 y)$} & \multirow{2}{*}{$\begin{array}{l}\text { Health Professionals } \\
\text { Follow-Up Study } \\
\text { participants (USA) }\end{array}$} & \multirow{2}{*}{$\begin{array}{l}\text { Both; } 40-75 \mathrm{y} \\
\mathrm{N}=42,730\end{array}$} & \multirow{2}{*}{ Semi-quantitative FFQ } & \multirow{2}{*}{$\begin{array}{l}\text { Predicted } \\
\text { 25(OH)D score } \\
\text { (quintiles) }\end{array}$} & $\begin{array}{l}\text { Tooth loss } \\
\text { incidence }\end{array}$ & $\begin{array}{l}\mathrm{HR}=0.90(95 \% \mathrm{CI}: \\
0.88-0.92) ; p<0.001 \text { for } \\
\text { trend (COX model) }\end{array}$ & \multirow{2}{*}{$\begin{array}{c}\text { Inverse } \\
\text { dose-dependent } \\
\text { associations }\end{array}$} & \multirow{2}{*}{ [26] } \\
\hline & & & & & $\begin{array}{l}\text { Self-reported } \\
\text { periodontitis }\end{array}$ & $\begin{array}{l}\mathrm{HR}=0.91(95 \% \mathrm{CI}: \\
0.86-0.95) ; p<0.001 \text { for } \\
\text { trend }(\mathrm{COX} \text { model) }\end{array}$ & & \\
\hline
\end{tabular}

${ }^{1}$ values compared highest vs. lowest percentile, ${ }^{2}$ values compared lowest vs. highest percentile, ${ }^{1} \mathrm{AAP} / \mathrm{CDC}$ criteria: PPD $\geq 5 \mathrm{~mm}$ on at least 1 tooth and CAL $\geq 6 \mathrm{~mm}$ at 2 or more sites (not on same tooth), ${ }^{2} \mathrm{ABL} \geq 40 \%$ at 3 or more sites. ${ }^{3} \mathrm{ABL} \geq 40 \%$ or $\geq 1$ tooth lost, ${ }^{4}$ IWCPDC criteria: ${ }^{3} \mathrm{BOP} \& \mathrm{PPD} \geq 3 \mathrm{~mm}$ at $\geq 1$ sites. AL $>2 \mathrm{~mm}$ or $\geq 1$ tooth lost, ${ }^{5} \geq 15$ sites with PPD $\geq 4 \mathrm{~mm}$. Abbreviations: 95\%CI: 95\% confidence interval, 25(OH)D: 25-hydroxyvitamin D, AAP: American Academy of Periodontology, ABL: alveolar bone loss, ACH: alveolar crestal height, BOP: bleeding on probing, CAL: clinical attachment loss, CC: case-control study, CDC: Center for Disease Control and Prevention, CS: cross-sectional study, DLS: Department of Veteran Affairs Dental Longitudinal Study, HR: hazard ratio, IWCPDC: International Workshop for the Classification of Periodontal Diseases \& Conditions in 1999, NHANES III: Third National Health and Nutrition Examination Survey, OR: odds ratio, PPD: periodontal probing pocket, US: United States, vs.: versus, w: weeks. 


\subsection{Vitamin $A$}

Vitamin $\mathrm{A}$ is a liposoluble vitamin can be present in different forms including retinol $\left(\mathrm{A}_{1}\right)$, retinal, 3,4-dehydroretinol $\left(\mathrm{A}_{2}\right)$ and 3-hydroxyretinol $\left(\mathrm{A}_{3}\right)$. However, it his known that about 50 possible carotenoids (a group lipid-soluble plant pigments) act as vitamin precursors, being $\beta$-carotene the most important. For this reason, it was also selected studies assessing levels or intake of carotenoids with provitamin A activity (mainly $\alpha$ - and $\beta$-carotene, and $\beta$-cryptoxanthin). Attending to that, seven publications were collected, although they contain only observational studies (Table 2), mostly cross-sectional studies. Among them, only three studies estimated dietary intakes of vitamin A. On one hand, Freeland et al. [36] reported a significant negative correlation at bivariate level between vitamin A intake and RPI in a smaller sample constituted by patients from a suburban dental clinic. Notwithstanding, these authors also analyzed the relationship with more nutrients and vitamin A intake was not considered among significant predictors in multiple analysis after using $\mathrm{R}^{2}$ improvement. Additionally, dietary intake data only were available from 56 of 80 patients, which could produce a selection bias that was no evaluated. On the other hand, a case-control study in female adolescent with and without gingivitis indicates absence of differences for both, intake or prevalence of marginal deficiencies of intake (below one third of recommendations) [37]. However, in the two first studies, dietary intakes were estimated by a $24 \mathrm{~h}$ recall and a 3 days food diary, respectively. Such information only represents current diet, which along with the possible memory errors and bias may not represent real nutritional status of the sample [20]. Anyway, most of studies have investigated possible associations of serum levels of vitamin A (or retinol) and different carotenoids with periodontal health. Results from one of these investigations are particularly significant due to it was performed with a sample of 11,480 adults from the third National Health and Nutrition Examination Survey (NHANES III), which are a representative of the United States (US) non-institutionalized population [38]. In this, significant associations with periodontitis were reported for $\alpha$-, $\beta$-carotene and $\beta$-cryptoxanthin when analysis was not restricted to most severe cases of periodontitis (defined by the presence of at least one site with CAL of $4 \mathrm{~mm}$ or higher and PPD of at least $4 \mathrm{~mm}$ ). Still, severe periodontitis (defined by the presence of two or more mesiobuccal sites with CAL of at least $5 \mathrm{~mm}$ and at least one mesiobuccal site with PPD of $4 \mathrm{~mm}$ or higher) was significantly associated with $\beta$-carotene and vitamin A [38]. In contrast, no significant associations with RPI was reported by the study in patients from a suburban dental clinic recently mentioned [36]. Moreover, as indicated, vitamin A intake was also not related to RPI in multiple analysis in the same study. Anyway, it is important to point out that blood samples were collected after no fasting indication in the last study. The combination of all this methodological issues along with the reduced subset of individuals evaluated would contribute to explain the absence of significant associations found in this study. In spite of most studies has been considered to evaluate vitamin A nutritional status by measurement of blood levels, there was also a study in an ethnic group from Sri Lanka that evaluated it by means of deficiency clinical symptoms presence, but no association was also found with RPI again [39]. However, in this last periodontal disease degree could be undervalued since oral examinations outside of University were made into bad conditions such as poor luminosity and non-appropriate chairs, among others. Despite these results, it is important to point out that Vitamin A is stored in the liver and serum levels are closely regulated, so low and deficient serum values are linked to depleted hepatic stores [40].

Other known risk factors have been also taken into account in many of the selected studies, especially age and smoking. Some studies have been performed only in elderly adults. These include a retrospective cohort study in 334 Japanese from Niigata city where dietary intakes of $\alpha$ - and $\beta$-carotene were estimated by a brief self-administered diet-history questionnaire (BDHQ) [41], and a cross-sectional in 1258 PRIME study participants (North Ireland) where serum levels of retinol, $\alpha$ and $\beta$-carotene, and $\beta$-cryptoxanthin were registered [42]. In spite of the first one only was focused in two carotenoids, it was noted a negative association between dietary $\beta$-carotene intake and no of teeth with periodontal disease progression, even after adjustment for several cofounders, although $\alpha$-carotene 
intake did not show association [42]. Unfortunately, the BDHQ did not include supplements and it was self-assessed.

Notwithstanding, the role of $\beta$-carotene was supported by results from the second study that was carried out in a sample with a considerable size. This also suggests an important role for $\beta$-cryptoxanthin, as well as for $\alpha$-carotene and retinol, but only when analysis were not restricted to more severe periodontitis cases. However, it is important to point out that participants were only men in the last one. Concerning smoking, in the study performed on data from NHANES III [38] only $\beta$-carotene levels maintain an inverse association with periodontitis when analysis was restricted to never-smokers. In this context, other studies adjusted OR by age or include smoking status as covariate in multiple models. This emphasizes the importance of these risk factors in periodontal health as well as their interaction with this group of nutrients. This suggests the existence of putative risk groups to recommend the consumption of vitamins A or pro-vitamins as nutraceutical in the context of periodontal health. However, the methodological approaches of the mentioned studies makes provided evidence no definitive to consider this group of nutrients as "nutraceutical" and some additional experimental, or at least cohort, studies are needed.

The biologically active form of vitamin A, retinoic acid, is essential for maintaining the integrity of mucosal tissues and for proper differentiation of cells, including those of the immune system [28,43]. According to this, it is expected that an adequate intake of this nutrient prevent periodontal disease onset or progression since it affect to connective tissue maintenance. Moreover, its role in immune system could be also important for maintain some bacteria adequate level and for prevent over-inflammation. However, as neither indicated studies specifically evaluating vitamin A intake did not support this [36,37]. In spite of this might mean a virtual absence of relationship between this nutrient and periodontal health, it is also important to consider that none divided sample by recommended dietary amount. Consequently, if deficiencies are rare in populations where the studies were carried out, relationship could be not be elucidated when this is not linear. Moreover, other investigators have reported antioxidant activities for retinol and dehydroretinol as well as for many pro-vitamin A compounds, including $\beta$ - and $\alpha$-carotenes [44,45]. However, $\beta$-carotene is an efficient quencher of singlet oxygen [46] but vitamin A (i.e., retinol and derivatives) cannot quench singlet oxygen and has a very small capacity to scavenge free radicals $[47,48]$. In addition, more studies and analysis reported associations for $\beta$-carotene than for retinol or vitamin A. This fact would be consistent with the possibility that this effect is due to its antioxidant activity and not as vitamin A precursor. Unfortunately, there were no measurements of oxidative stress levels in the studies presented in this review. 
Table 2. Observational studies on association of vitamin and provitamins A with periodontal disease.

\begin{tabular}{|c|c|c|c|c|c|c|c|c|}
\hline $\begin{array}{c}\text { Study } \\
\text { Type }\end{array}$ & Sample & Sex; Age; N & $\begin{array}{l}\text { Dietary Intake } \\
\text { Assessment }\end{array}$ & $\begin{array}{c}\text { Nutritional Status } \\
\text { Assessment }\end{array}$ & Periodontal Status & Analysis Results ( $p$-Value) & Main Results/Conclusions & Ref \\
\hline CS & $\begin{array}{l}\text { Dental clinic } \\
\text { patients (USA) }\end{array}$ & $\begin{array}{l}\text { Both; N.A.; } \\
\quad \mathrm{N}=80\end{array}$ & $\begin{array}{l}\text { Dietary intakes of } \\
\text { vitamin A by 24-h } \\
\text { recall }(\mathrm{N}=56)\end{array}$ & $\begin{array}{l}\text { Serum levels of } \\
\text { vitamin A }\end{array}$ & RPI & $\begin{array}{l}\text { N.S. (mult. linear reg with } R^{2} \\
\text { improvement) }\end{array}$ & No associations & [36] \\
\hline CS & $\begin{array}{c}\text { Ethnic group } \\
\text { subjects (Sri Lanka) }\end{array}$ & $\begin{array}{l}\text { Both; } \geq 13 \mathrm{y} \\
\mathrm{N}=7944\end{array}$ & - & $\begin{array}{l}\text { Vitamin A deficiency } \\
\text { determined by } \\
\text { clinical symptoms }\end{array}$ & RPI & N.S. (mult. linear reg.) & No association & [39] \\
\hline \multirow{13}{*}{ CS } & \multirow{13}{*}{$\begin{array}{c}\text { NHANES III } \\
\text { participants (USA) }\end{array}$} & \multirow{13}{*}{$\begin{array}{l}\text { Both; } \geq 20 \text { y; } \\
\mathrm{N}=11,480\end{array}$} & \multirow{13}{*}{ - } & \multirow{3}{*}{$\begin{array}{l}\text { Serum levels of } \\
\alpha \text {-carotene } \\
\text { (quintiles) }\end{array}$} & \multirow{2}{*}{ Mild periodontitis ${ }^{3}$} & $\begin{array}{c}\left.\mathrm{OR}^{1}=0.60 \text { (95\%CI: } 0.46-0.77\right) \\
p=0.0009 \text { for trend (mult. logistic reg.) } \\
\text { in non-restricted model }\end{array}$ & \multirow{13}{*}{$\begin{array}{c}\text { Negative association of } \beta \text {-\& } \\
\alpha \text {-carotene, \& } \\
\beta \text {-Cryptoxanthin with mild } \\
\text { periodontitis; \& of } \\
\beta \text {-carotene \& vitamin A } \\
\text { with severe periodontitis }\end{array}$} & \multirow{13}{*}{ [38] } \\
\hline & & & & & & $\begin{array}{l}\text { N.S. (mult. logistic reg.) in model } \\
\text { restricted to never-smokers }\end{array}$ & & \\
\hline & & & & & Severe periodontitis ${ }^{4}$ & N.S. (mult. logistic reg.) in both models & & \\
\hline & & & & \multirow{4}{*}{$\begin{array}{l}\text { Serum levels of } \\
\beta \text {-carotene } \\
\text { (quintiles) }\end{array}$} & \multirow[t]{2}{*}{ Mild periodontitis ${ }^{3}$} & $\begin{array}{c}\left.\mathrm{OR}^{1}=0.80 \text { (95\%CI: } 0.65,0.98\right) \\
p=0.0001 \text { for trend (mult. logistic reg.) } \\
\quad \text { in non-restricted model }\end{array}$ & & \\
\hline & & & & & & $\begin{array}{c}\left.\mathrm{OR}^{1}=0.99 \text { (95\%CI: } 0.73-1.35\right) \\
p=0.044 \text { for trend (mult. logistic reg.) } \\
\text { in model restricted to never-smokers }\end{array}$ & & \\
\hline & & & & & \multirow[t]{2}{*}{ Severe periodontitis ${ }^{4}$} & $\begin{array}{c}\left.\mathrm{OR}^{1}=0.65 \text { (95\%CI: } 0.46-0.93\right) ; \\
p=0.001 \text { (mult. logistic reg.) in } \\
\text { non-restricted model }\end{array}$ & & \\
\hline & & & & & & $\begin{array}{l}\text { N.S. (mult. logistic reg.) in model } \\
\text { restricted to never-smokers }\end{array}$ & & \\
\hline & & & & \multirow{3}{*}{$\begin{array}{l}\text { Serum levels of } \\
\beta \text {-cryptoxanthin } \\
\quad \text { (quintiles) }\end{array}$} & \multirow[t]{2}{*}{ Mild periodontitis ${ }^{3}$} & $\begin{array}{c}\left.\mathrm{OR}^{2}=0.74 \text { (95\%CI: } 0.61-0.89\right) p=0.03 \\
\text { for trend (mult. logistic reg.) in } \\
\text { non-restricted model }\end{array}$ & & \\
\hline & & & & & & $\begin{array}{l}\text { N.S. (mult. logistic reg.) in model } \\
\text { restricted to never-smokers }\end{array}$ & & \\
\hline & & & & & Severe periodontitis ${ }^{4}$ & N.S. (mult. logistic reg.) in both models & & \\
\hline & & & & \multirow{3}{*}{$\begin{array}{c}\text { Serum levels of } \\
\text { vitamin A (quintiles) }\end{array}$} & Mild periodontitis ${ }^{3}$ & N.S. (mult. logistic reg.) in both models & & \\
\hline & & & & & \multirow[t]{2}{*}{ Severe periodontitis ${ }^{4}$} & $\begin{array}{c}\left.\mathrm{OR}^{1}=0.77 \text { (95\%CI: } 0.58-1.03\right) p=0.049 \\
\text { for trend (mult. logistic reg.) in } \\
\text { non-restricted model }\end{array}$ & & \\
\hline & & & & & & $\begin{array}{l}\text { N.S. (mult. logistic reg.) in model } \\
\text { restricted to never-smokers }\end{array}$ & & \\
\hline
\end{tabular}


Table 2. Cont.

\begin{tabular}{|c|c|c|c|c|c|c|c|c|}
\hline $\begin{array}{l}\text { Study } \\
\text { Type }\end{array}$ & Sample & Sex; Age; $N$ & $\begin{array}{c}\text { Dietary Intake } \\
\text { Assessment }\end{array}$ & $\begin{array}{c}\text { Nutritional Status } \\
\text { Assessment }\end{array}$ & Periodontal Status & Analysis Results ( $p$-Value) & Main Results/Conclusions & Ref \\
\hline \multirow{8}{*}{ CS } & \multirow{8}{*}{$\begin{array}{l}\text { Participants in } \\
\text { PRIME (Northern } \\
\text { Ireland) }\end{array}$} & \multirow{8}{*}{$\begin{array}{l}\text { Male; } 60-70 \text { y; } \\
\quad \text { N = } 1258\end{array}$} & \multirow{8}{*}{-} & \multirow{2}{*}{$\begin{array}{l}\text { Serum levels of } \\
\text { retinol (quintiles) }\end{array}$} & $\begin{array}{l}\text { Low-threshold } \\
\text { periodontitis }\end{array}$ & $\begin{array}{c}\mathrm{OR}^{2}=1.64 \text { (95\%CI: 1.07-2.51); } \\
p=0.008 \text { for trend (mult. logistic reg.) }\end{array}$ & \multirow{8}{*}{$\begin{array}{l}\text { Negative association of } \\
\text { serum levels of } \beta \text {-carotene } \\
\& \beta \text {-cryptoxanthin at both } \\
\text { tresholds, \& also of } \\
\alpha \text {-carotene only at } \\
\text { low-threshold }\end{array}$} & \multirow{8}{*}{ [42 } \\
\hline & & & & & $\begin{array}{l}\text { High-threshold } \\
\text { periodontitis }\end{array}$ & N.S. (mult. logistic reg.) & & \\
\hline & & & & $\begin{array}{c}\text { Serum levels of } \\
\alpha \text {-carotene }\end{array}$ & $\begin{array}{l}\text { Low-threshold } \\
\text { periodontitis }\end{array}$ & $\begin{aligned} \mathrm{OR}^{2} & =1.81 \text { (95\%CI: } 1.17-2.82) ; p<0.001 \\
& \text { for trend (mult. logistic reg.) }\end{aligned}$ & & \\
\hline & & & & (quintiles) & $\begin{array}{l}\text { High-threshold } \\
\text { periodontitis }\end{array}$ & N.S. (mult. logistic reg.) & & \\
\hline & & & & \multirow{2}{*}{$\begin{array}{l}\text { Serum levels of } \\
\beta \text {-carotene } \\
\text { (quintiles) }\end{array}$} & $\underset{5}{\text { Low-thresholdperiodont }}$ & $\begin{aligned} \text { tioR }^{2} & =1.83 \text { (95\%CI: } 1.19-2.80) ; p<0.001 \\
& \text { for trend (mult. logistic reg.) }\end{aligned}$ & & \\
\hline & & & & & $\begin{array}{l}\text { High-threshold } \\
\text { periodontitis }\end{array}$ & $\begin{array}{l}\left.\mathrm{OR}^{2}=1.87 \text { (95\%CI: } 0.86-4.06\right) ; p=0.01 \\
\quad \text { for trend (mult. logistic reg.) }\end{array}$ & & \\
\hline & & & & \multirow{2}{*}{$\begin{array}{l}\text { Serum levels of } \\
\beta \text {-cryptoxanthin } \\
\text { (quintiles) }\end{array}$} & $\begin{array}{l}\text { Low-threshold } \\
\text { periodontitis }\end{array}$ & $\begin{array}{l}\left.\mathrm{OR}^{2}=1.50 ; 95 \% \text { CI: } 0.99-2.27\right) ; p=0.02 \\
\quad \text { for trend (mult. logistic reg.) }\end{array}$ & & \\
\hline & & & & & $\begin{array}{l}\text { High-threshold } \\
\text { periodontitis }\end{array}$ & $\begin{array}{l}\left.\mathrm{OR}^{2}=4.02 \text { (95\%CI: } 1.61-9.99\right) ; p=0.001 \\
\quad \text { for trend (mult. logistic reg.) }\end{array}$ & & \\
\hline \multirow[b]{2}{*}{ CC } & \multirow[b]{2}{*}{$\begin{array}{l}\text { Non-smokers } \\
\text { adolescents (Italy) }\end{array}$} & \multirow[b]{2}{*}{$\begin{array}{l}\text { Female; } 17-19 \text { y; } \\
\quad \mathrm{N}=54\end{array}$} & $\begin{array}{l}\text { Dietary intake of } \\
\text { vitamin A by 3-d } \\
\text { record }\end{array}$ & & \multirow[b]{2}{*}{$\begin{array}{l}\text { Gingivitis affected }{ }^{7} \text { vs. } \\
\text { non-affected }\end{array}$} & $\begin{array}{l}\text { N.S. differences between groups } \\
\text { (Student } t \text { test) }\end{array}$ & \multirow[b]{2}{*}{ No association } & \multirow[b]{2}{*}[37]{} \\
\hline & & & $\begin{array}{c}\text { Dietary intake } \\
\text { marginal deficiency } \\
(<1 / 3 \text { RDA) of } \\
\text { vitamin A by 3-d } \\
\text { record }\end{array}$ & - & & N.S. ( $X^{2}$ test with Yates correction) & & \\
\hline \multirow{2}{*}{ RC (2 y) } & \multirow{2}{*}{$\begin{array}{c}\text { Niigata study } \\
\text { participants (Japan) }\end{array}$} & \multirow{2}{*}{$\begin{array}{l}\text { Both; } 75 \text { y; } \\
\text { N = } 334\end{array}$} & $\begin{array}{l}\text { Dietary intakes of } \\
\alpha \text {-carotene (tertiles) } \\
\text { by BDHQ }\end{array}$ & \multirow[b]{2}{*}{ - } & \multirow{2}{*}{$\begin{array}{l}\text { No. of teeth with } \\
\text { periodontal disease } \\
\text { progression }{ }^{8}\end{array}$} & N.S. (mult. logistic reg.) & \multirow{2}{*}{$\begin{array}{l}\text { Negative association with } \\
\beta \text {-carotene intake }\end{array}$} & \multirow{2}{*}{ [41] } \\
\hline & & & $\begin{array}{l}\text { Dietary intakes of } \\
\beta \text {-carotene (tertiles) } \\
\text { by BDHQ }\end{array}$ & & & $\begin{array}{l}\text { IRR }^{1}=0.73 \text { (95\%CI: 0.56-0.95); } p<0.05 \\
\quad \text { for trend (mult. logistic reg.) }\end{array}$ & & \\
\hline
\end{tabular}

${ }^{1}$ values compared highest vs. lowest percentile, ${ }^{2}$ values compared lowest $\mathrm{t}$ vs. highest percentile, ${ }^{3}$ at least 1 site with CAL $\geq 4 \mathrm{~mm} \& \mathrm{PPD} \geq 4 \mathrm{~mm},{ }^{4} \geq 2 \mathrm{mesiobuccal}$ sites with CAL $\geq 5$ $\mathrm{mm} \& 1$ mesiobuccal sites with PPD $\geq 4 \mathrm{~mm},{ }^{5}$ at least 2 teeth with non-contiguous inter-proximal sites with CAL $\geq 6 \mathrm{~mm} \& 1$ PPD of $\geq 5 \mathrm{~mm},{ }^{6} \geq 15 \%$ of all sites measured CAL $\geq 6 \mathrm{~mm} \&$ there was at least one site with PPD $\geq 6 \mathrm{~mm},{ }^{7} \geq 1$ site with BOP, ${ }^{8} \mathrm{CAL} \geq 3 \mathrm{~mm}$ in $\geq 1$ site. Abbreviations: $95 \% \mathrm{CI}$ : $95 \%$ confidence interval, BDHQ: brief diet-history questionnaire, BOP: Bleeding on probing; C: Cohort study, CAL: Clinical attachment loss, CPI: Community periodontal index; CS: Cross-sectional study; d: days, h: hours, IRR: incidence rate ratio, mult.: multiple, N: sample size, N.S.: not significant, NHANES III: Third National Health and Nutrition Examination Survey, OR: Odds ratio, PRIME: Prospective Epidemiological Study of Myocardial Infarction, PPD: periodontal pocket depth, RC: retrospective cohort study, RDA: recommended dietary amount, Ref: reference, reg.: regression, RPI: Russell's Periodontal Index, SD: Standard deviation; US: United states, vs.: versus, y: years. 


\subsection{Vitamin B-Complex}

Vitamin B-complex refers to all of the known essential water-soluble vitamins except for vitamin C. These include thiamine (vitamin $B_{1}$ ), riboflavin (vitamin $B_{2}$ ), niacin (vitamin $B_{3}$ ), pantothenic acid (vitamin $B_{5}$ ), pyridoxine (vitamin $B 6$ ), biotin (vitamin $B_{7}$ or $B_{8}$ ), folic acid (vitamin $B_{9}$ ) and cobalamin (vitamin $\mathrm{B}_{12}$ ) [49]. Four observational studies in humans, three cross-sectional studies and a case-control study met the eligibility criteria for vitamins belonging to B-complex. Concerning to experimental research there was only one report focusing on a nutritional intervention in human beings [50]. Overall, vitamin B-complex is necessary for cell growth and metabolism [49], but each member of the B-complex has a unique structure and performs unique functions. Vitamins $B_{1}, B_{2}, B_{3}$, and biotin participate in different aspects of energy production, vitamin B6 is essential for amino acid metabolism, and vitamin $\mathrm{B}_{12}$ and folic acid facilitate steps required for cellular division [50-52].

The most promising results for this group of nutrients has been offered by a randomized placebo-controlled double-blind trial (Table 3) where it was tested the effect of a vitamin B-complex supplement (50 mg of $\mathrm{B}_{1}, \mathrm{~B}_{5}, \mathrm{~B}_{2}, \mathrm{~B}_{3}$, and $\mathrm{B}_{6} ; 50 \mu \mathrm{g}$ of $\mathrm{B}_{12}$ and $\mathrm{B}_{7}$; and $400 \mu \mathrm{g}$ of $\mathrm{B}_{9}$ ) after access flap surgery. After 30 days of treatment, the supplement led to statistically significant superior CAL gains when compared to placebo, although PPD improved in a similar manner in all groups [50]. However, currently it is assumed that PPD alone does not reliably reflect whether teeth have progressive CAL, except in sites with deep PPD. This would support the use of vitamin B-complex supplements as nutraceutical to restore periodontal health, at least in combination with surgical interventions.

On the other hand, no associations were observed in the older investigation that analyzed clinical sings of vitamin B deficiency in relation to RPI previously indicated for vitamin A [39]. However, as mentioned, in this last periodontal disease degree could be undervalued since some oral examinations were made into bad conditions. Notwithstanding, more studies exploring the use of vitamin B-complex as nutraceutical under different conditions are needed prior to encourage its use in relation to periodontal disease. 
Table 3. Experimental studies on vitamin effects on periodontal disease.

\begin{tabular}{|c|c|c|c|c|}
\hline Subjects/Animals; Age; $\mathbf{N}$ & Experimental Design (Duration) & Results Data ( $p$-Value) & Main Results/Conclusions & Ref. \\
\hline & \multirow{2}{*}{$\begin{array}{l}\text { RCT (DB) B-complex supplement for } 30 \mathrm{~d}(50 \mathrm{mg} \\
\text { of } B_{1}, B_{5}, B_{2}, B_{3} \text {, and } B_{6} ; 50 \mu \mathrm{g} \text { of } B_{12} \text { and } B_{7} ; \text { and } \\
\left.400 \mu \mathrm{g} \text { of } B_{9}\right) \text { after access flap surgery }(180 \mathrm{~d})\end{array}$} & $\Delta$ CAL: $0.41>-0.52 \mathrm{~mm}(p=0.024)$ & \multirow{2}{*}{$\begin{array}{l}\text { B-complex led to superior CAL gains when } \\
\text { compared to placebo whereas PPD improved } \\
\text { in similar manner among groups }\end{array}$} & \multirow{2}{*}[50]{} \\
\hline & & $\Delta \mathrm{PPD}:-1.50 \pm 0.21=-1.57 \pm 0.34 \mathrm{~mm}$ (N.S.) & & \\
\hline $\begin{array}{l}\text { Calculus formers from Staff \& patients } \\
\text { from a Faculty of Odontology (Sweden); } \\
\text { Age not provided; } N=60\end{array}$ & $\begin{array}{l}\text { Chew on } 0 \text { or } 5 \text { sugar free gum } / \text { day contained } 60 \\
\mathrm{mg} \text { or } 0 \mathrm{mg} \text { vitamin } \mathrm{C}(\mathrm{CO})(3 \mathrm{~m} \text { per treatment })\end{array}$ & $\begin{array}{c}\text { Calculus index, Erosion scores, GB, visible PI, \& saliva } \\
\text { secretion rates }(p<0.05)\end{array}$ & $\begin{array}{c}\text { Vitamin C \& non-vitamin gum reduced } \\
\text { visible plaque, but No. of bleeding sites only } \\
\text { with the first one }\end{array}$ & [53] \\
\hline $\begin{array}{c}\text { Children with } \leq 1 \text { fully erupted tooth } \\
\text { following routine prophylaxis; } 5-20 \mathrm{y} ; \mathrm{N} \\
=267\end{array}$ & $\begin{array}{l}\text { Chew on tablets containing vitamin } C \text { or mannitol } \\
\text { (DB) (28 d) }\end{array}$ & RPI (N.S.) Teeth lost (N.S.) & No effect & [54] \\
\hline $\begin{array}{l}\text { Chronic periodontitis patients with } \leq 20 \\
\text { teeth receiving non-surgical treatment \& } \\
\text { health Subjects (Syria); } 23-65 \text { y; } N=60\end{array}$ & $\begin{array}{l}\text { Adjunctive dose of vitamin } \mathrm{C} \text { or none ( } 4 \mathrm{w} \text { after } \\
\text { non-surgical treatment) }\end{array}$ & Plasma TAOC, PPD, CAL, \% BOP, PI \& GI & $\begin{array}{l}\text { Non-surgical treatment increases plasma } \\
\text { TAOC \& improves clinical measures, but } \\
\text { vitamin C supplements have no effect }\end{array}$ & [55] \\
\hline $\begin{array}{l}\text { Patients with vary degrees of gingivitis } \\
\text { (USA); } 25-60 \text { y; } \mathrm{N}=41\end{array}$ & $\begin{array}{l}\text { Vitamin C-supplemented or non-supplemented } \\
\text { diet (14 d), after receiving scaling \& curettage } \\
\text { therapy in one quadrant or not }\end{array}$ & $\begin{array}{l}\text { Levels of vitamin C in blood \& gingiva, microscopy } \\
\text { evaluation of gingival biopsies }\end{array}$ & $\begin{array}{l}\text { Vitamin C supplementation increased } \\
\text { Vitamin C levels in blood }\end{array}$ & [56] \\
\hline Male Wistar rats; $8 \mathrm{w} ; \mathrm{N}=35$ & $\begin{array}{l}\text { Ligatures placement or not placement }(6 \mathrm{w}) \\
\text { combined or not with vitamin C supplementation } \\
\text { (last } 2 \mathrm{w})\end{array}$ & $\begin{array}{l}\text { Plasma levels of vitamin C \& ROM, gingival } \\
\text { GSH/GSSG \& levels of 8-OhdG } \\
\text { Genetic expresion study in gums }{ }^{1}\end{array}$ & $\begin{array}{l}\text { Vitamin C increased plasma vitamin C level, } \\
\text { improved GSH/GSSG \& decreased 8-OHdG } \\
\text { level ( } 61 \% \text { lower) \& down-regulated some } \\
\text { inflammation genes expression }(p<0.01)\end{array}$ & [57] \\
\hline Male Wistar rats; N.A.; $\mathrm{N}=36$ & $\begin{array}{l}\text { Ligatures placement or not placement }(7 \mathrm{w}) \\
\text { combined or not with supplemens of vitamin C } \\
\text { (last } 2 \mathrm{w})\end{array}$ & $\begin{array}{l}\text { Serum levels of BAP, gingival MPO activity, RANKL } \\
\text { expression, BDI in mandible }\end{array}$ & $\begin{array}{l}\text { Either supplement led to lower MPO activity, } \\
\text { \& RANKL expression, but higher AP; \& } \\
\text { improved BDI at the periodontitis areas }\end{array}$ & [58] \\
\hline
\end{tabular}


Table 3. Cont.

\begin{tabular}{|c|c|c|c|c|}
\hline Subjects/Animals; Age; $\mathbf{N}$ & Experimental Design (Duration) & Results Data ( $p$-Value) & Main Results/Conclusions & Ref. \\
\hline Male Wistar rats; $8 \mathrm{w} ; \mathrm{N}=24$ & $\begin{array}{l}1 \text { or } 2 \text { folds vitamin C-supplemented } \\
\text { high-cholesterol diet, non-supplemented, or } \\
\text { standard diet }(12 \mathrm{w})\end{array}$ & $\begin{array}{l}\text { Alveolar BMD, TRAP-positive osteoclastic cells \& } \\
\text { 8-OHdG level in periodontal tissues } \\
\text { 8-OHdG }(1663 \& \text { \& } 1675 \mathrm{mg} / \mathrm{cm} \text { in vitamin C groups vs. } \\
1430(-80) \mathrm{mg} / \mathrm{cm} \text { in cholesterol group, } p<0.001 \text { and } \\
\text { vs. } 1556 \mathrm{mg} / \mathrm{cm} \text { in control groups, } p<0.05), \text { osteoclast } \\
\text { differentiation }(1.1 \& 0.8 \text { vs. } 4.2 \text { No. of tartrate-resistant } \\
\text { acid phosphatase [TRAP]-positive osteoclasts } / 0.1 \mathrm{~mm} \text {, } \\
p<0.05) \& \text { \&ecreased serum } 8 \text {-OHdG expression }(0.12 \\
\text { \& } 0.10 \text { vs. } 0.14 \mathrm{ng} / \mathrm{mL}, p<0.05)\end{array}$ & $\begin{array}{l}\text { Vitamin C supplements reduced the effect of } \\
\text { high-cholesterol diet on BMD, osteoclast } \\
\text { differentiation \& decreased 8-OhdG and } \\
\text { osteoclast differentiation kit }\end{array}$ & [59] \\
\hline $\begin{array}{c}\text { Male rats with non-osteogenic } \\
\text { hereditary disorder (ODS od /od) \& } \\
\text { without it (ODS }+/+ \text { ) } 5 \text { w } ; \mathrm{N}=28\end{array}$ & $\begin{array}{l}\text { Vitamin C-deficient, minimally supplemented or } \\
\text { sufficient supplemented diet in non-osteogenic } \\
\text { disorder group }(4 \mathrm{w})\end{array}$ & $\begin{array}{l}\text { Plasma level of vitamin C, histological observations of } \\
\text { periodontium, BMD \& cephalometric evaluation }\end{array}$ & $\begin{array}{l}\text { Vitamin C deficiency influenced periodontal } \\
\text { ligament \& craniofacial growth }\end{array}$ & [60] \\
\hline Male Wistar rats; $180-220 \mathrm{~g} ; \mathrm{N}=72$ & $\begin{array}{l}\text { Vitamin E supplements or placebo; combined } \\
\text { with ligatures placement or sham-operations ( } 9 \mathrm{~d} \text { ) }\end{array}$ & $\begin{array}{l}\text { ABL \& malondialdehyde formation, SOD activity, } \\
\text { iNOS \& TNF- } \alpha \text { levels }(1.89 \pm 0.35 \text { vs. } 3.13 \pm 0.42 \mathrm{mM} \\
\text { of malondialdehyde, } p<0.01)\end{array}$ & $\begin{array}{l}\text { Vitamin E prevented malondialdehyde } \\
\text { formation \& reduced the immunoreactivity } \\
\text { to iNOS levels }\end{array}$ & [61] \\
\hline Male rice rats; $92-119 \mathrm{~d} ; \mathrm{N}=32$ & $\begin{array}{c}\text { Vitamin E supplemented or non-supplemented } \\
\text { diet (122 d), combined with stress by a rotational } \\
\text { device (last } 90 \mathrm{~d})\end{array}$ & $\begin{array}{c}\mathrm{ABL}(0.369 \pm 0.091 \text { vs. } 0.436 \pm 0.036 \mathrm{~mm} \text { of } \mathrm{CEJ}-\mathrm{ABC} \\
\qquad p=0.017)\end{array}$ & $\begin{array}{c}\text { Vitamin E had a protective effect on bone loss } \\
\text { which was most pronounced at sites most } \\
\text { susceptible to loss }\end{array}$ & [62] \\
\hline
\end{tabular}

${ }^{1}$ Genetic expression analysis for 86 genes implicated on: oxidative or metabolic stress, heat shock, proliferation and carcinogenesis, growth arrest and senescence, and necrosis or apoptosis. Abbreviations: 8-OHdG: 8-hydroxydeoxyguanosine, ABL: alveolar bone loss; BAP: bone alkaline phosphatase, BDI: Bone Density Index, BI: Bleeding index, BMD: Bone mass density, BOP: Bleeding on probing, CAL: Clinical attachment level, CO: Cross-over, d: days, DB: Double-bind, GB: gingival bleeding, GI: Gingival index, GSH/GSSG: reduced glutathione to oxidized glutathione ratio, IL: Interleukin, iNOS: Inducible nitric oxide synthase, m: moth, MPO: Myeloperoxidase, ODS: Osteogenic disorder Shionogi, PI: Plaque index, PPD: Periodontal probing depth, RANKL: Receptor activator of nuclear factor KB ligand, RCT: Randomized controlled trial, ROM: Reactive oxygen metabolites, RPI: Russell's periodontal index, SOD: Superoxide dismutase, TAOC: total antioxidant capacity, TNF- $\alpha$ : Tumor necrosis factor alpha, TRAP: Tartrate-resistant acid phosphatase, US: United Sates of America, w: weeks, y: years. 
There is little information about the separate role of the different components of this complex, although observational studies provide some information in this sense (Table 4). Among all vitamins of the B-complex, folic acid seems to be the most interesting. Actually, two of the selected cross-sectional studies for vitamin B-complex only evaluated associations with this vitamin, but when their results are combined, a clear association cannot be established. One performed with data from elderly participants from the 2001-2002 National Health and Nutrition Examination Survey (NHANES) showed that low serum folate level was independently associated with periodontal disease (defined by the presence of at least of $10 \%$ of sites with CAL of $4 \mathrm{~mm}$ or higher and/or PPD of at least $3 \mathrm{~mm}$ ) [63]. In contrast, in other study based on a representative sample of adults from Japan, no association between risk of periodontal disease (defined by a CPI of 3 or more) and dietary intake estimations was found [64]. Similarly, another study that only included non-smokers subjects [65] reported no correlation of dietary intake with CPI score (i.e., periodontal disease severity) although it was inversely associated with percentage of sites with BOP. Despite low values of CPI reflect gingival bleeding and calculus, when it reach values of 3 or higher is only based on PPD and provides no information about bleeding or calculus presence. Therefore, the last study suggests that folic acid intake could be important for prevention of gingival inflammation, although the relationship with periodontal pocket formation and development is unclear. Notwithstanding, in this study only were included non-smokers individuals. In addition, they were adults belonging to any age. This could indicate that smoking and age and important risk factor interacting with vitamin $\mathrm{B}_{9}$, but bias associated with dietary intake assessment methods also could lead to underestimating the effect of this nutrient.

The role in periodontal disease of other vitamins belonging to B-complex has been also evaluated in an observational study but no clear association has been found for them. In the study carried out in patients from a dental clinic [36], there was no correlation between RPI (that scored the presence and severity of both gingival bleeding and pocket depth) and the dietary intakes of the three vitamins measured, thiamine, niacin and riboflavin. The same vitamins were also analyzed in the study in female adolescents from Rome already mentioned for vitamin A with results that could results interesting to clarify their roles of some vitamin B, at least at gingival inflammation level. In this case, gingivitis-affected presented lower dietary intakes of vitamins $B_{1}$ and $B_{2}$ with respect to those non-affected, but $B_{2}$ was the only that remained significant in multiple logistic regression analysis. This only occurred in one of the models used in that fiber was not included, whereas in the other two that did it, Vitamin $B_{2}$ was substituted by calcium. Authors concluded that both nutrients as strong correlated as consequence of high milk intake, so real cause for this association remain unclear [37]. Moreover, association with dietary intake of vitamin $B_{12}$ was also evaluated in the study based on a representative sample of Japanese adults, but no significant results were reported [64]. Therefore, the paucity of studies on individual vitamins B role in periodontal health does not allow recommending supplementation with a particular vitamin B with a nutraceutical objective, although folic acid is an important candidate. In any case, the results from the RCT with B-complex supplement [50] are promising and more studies in human should be done with such combination. 
Table 4. Observational studies on vitamin B-complex association with periodontal disease.

\begin{tabular}{|c|c|c|c|c|c|c|c|c|}
\hline $\begin{array}{l}\text { Study } \\
\text { Type }\end{array}$ & Sample & Sex; Age; N & Dietary Intake Assessment & $\begin{array}{l}\text { Nutritional Status } \\
\text { Assessment }\end{array}$ & Periodontal Status & Analysis Results ( $p$-Value) & $\begin{array}{c}\text { Main } \\
\text { Results/Conclusions }\end{array}$ & Ref \\
\hline CS & $\begin{array}{l}\text { NHANES 2001/02 } \\
\text { Participants (US) }\end{array}$ & Both; $\geq 60$ y; $N=844$ & - & $\begin{array}{l}\text { Serum levels of } \\
\text { vitamin } B_{9} \\
\text { (quartiles) }\end{array}$ & Periodontal disease $^{2}$ & $\begin{array}{c}\left.\mathrm{OR}^{1}=0.28 \text { (95\%CI: } 0.30-1\right) ; p \\
=0.03 \text { for trend (mult. logistic } \\
\text { reg.) }\end{array}$ & Negative association & {$[63]$} \\
\hline \multirow{2}{*}{ CS } & \multirow{2}{*}{$\begin{array}{c}\text { Non-smokers adults } \\
\text { (Japan) }\end{array}$} & \multirow{2}{*}{ Both $; \geq 18$ y; $N=497$} & \multirow{2}{*}{ Dietary intake of vitamin $B_{9}$} & \multirow[t]{2}{*}{ - } & CPI & N.S. (mult. logistic reg.) & \multirow{2}{*}{$\begin{array}{l}\text { Negative association } \\
\quad \text { with \% BOP }\end{array}$} & \multirow{2}{*}[64]{} \\
\hline & & & & & $\%$ BOP & $\begin{array}{c}\beta=-0.204 ; p<0.001 \text { (mult. } \\
\text { logistic reg.) }\end{array}$ & & \\
\hline CS & $\begin{array}{c}\text { NHANES } \\
\text { participants (Japan) }\end{array}$ & $\begin{array}{l}\text { Both; } \geq 20 y \\
\mathrm{~N}=3043\end{array}$ & $\begin{array}{c}\text { Dietary intake of vitamins } B_{9} \\
\text { \& } B_{12} \text { by FFQ }\end{array}$ & - & $\mathrm{CPI}=3-4$ & N.S. (mult. logistic reg.) & No associations & [65] \\
\hline CS & $\begin{array}{l}\text { Dental clinic } \\
\text { patients (US) }\end{array}$ & Both; N / A; N = 80 & $\begin{array}{l}\text { Dietary intakes of vitamins } B_{1} \\
\quad B_{2} \& B_{3}(N=56)\end{array}$ & - & RPI & $\begin{array}{c}\text { N.S. (mult. linear reg. with } R^{2} \\
\text { improvement) }\end{array}$ & No associations & {$[36]$} \\
\hline CS & $\begin{array}{l}\text { Subjects from an } \\
\text { ethnic group (Sri } \\
\text { Lanka) }\end{array}$ & $\begin{array}{l}\text { Both; }>13 \mathrm{y} \\
\mathrm{N}=7944\end{array}$ & - & $\begin{array}{l}\text { Vitamin B deficiency } \\
\text { determined by } \\
\text { clinical symptoms }\end{array}$ & RPI & N.S. (mult. linear reg.) & No association & [39] \\
\hline \multirow{8}{*}{ CC } & \multirow{8}{*}{$\begin{array}{l}\text { Non-smokers } \\
\text { adolescents (Italy) }\end{array}$} & \multirow{8}{*}{$\begin{array}{l}\text { Female; } 17-19 \mathrm{y} \\
\quad \mathrm{N}=54\end{array}$} & \multirow{2}{*}{$\begin{array}{l}\text { Dietary intakes of vitamin } B_{1} \\
\text { by 3-d record }\end{array}$} & \multirow{8}{*}{ - } & \multirow{8}{*}{$\begin{array}{l}\text { Gingivitis affected }{ }^{3} \text { vs. } \\
\text { non-affected }\end{array}$} & $\begin{array}{c}0.6( \pm 0.2)<0.9( \pm 0.3) \mathrm{mg} / \mathrm{d} \\
p=0.001 \text { (Student } t \text { test) }\end{array}$ & \multirow{8}{*}{$\begin{array}{l}\text { Negative association } \\
\text { with vitamin } B_{2} \\
\text { intake }\end{array}$} & \multirow{8}{*}{ [37] } \\
\hline & & & & & & $\begin{array}{l}\text { N.S. (Stepwise Mult. } \\
\text { logistic reg.) }\end{array}$ & & \\
\hline & & & \multirow{2}{*}{$\begin{array}{l}\text { Dietary intakes of vitamin } B_{2} \\
\text { by 3-d record }\end{array}$} & & & $\begin{array}{c}1.1( \pm 0.3)<1.4( \pm 0.3) \mathrm{mg} / \mathrm{d} \\
p=0.0009 \text { (Student } t \text { test) }\end{array}$ & & \\
\hline & & & & & & $\begin{array}{c}\text { OR }=0.06 \text { (96\%CI: } 0.01-0.35) \\
p=0.002 \text { (Stepwise Mult. } \\
\text { logistic reg.) }\end{array}$ & & \\
\hline & & & $\begin{array}{l}\text { Dietary intakes of vitamin } B_{3} \\
\text { by 3-d record }\end{array}$ & & & N.S. (Student $t$ test) & & \\
\hline & & & $\begin{array}{l}\text { Dietary intakes marginal } \\
\text { deficiency }(<2 / 3 \mathrm{RDA}) \text { of } \\
\text { vitamin } \mathrm{B}_{1} \text { by } 3 \text {-d record }\end{array}$ & & & $\begin{array}{l}51.9>22.2 \% ; p=0.04\left(X^{2} \text { test }\right. \\
\text { with Yates correction) }\end{array}$ & & \\
\hline & & & $\begin{array}{l}\text { Dietary intakes marginal } \\
\text { deficiency }(<2 / 3 \mathrm{RDA}) \text { of } \\
\text { vitamin } \mathrm{B}_{2} \text { by } 3 \text {-d record }\end{array}$ & & & $\begin{array}{l}29.6>0 \% p=0.007\left(X^{2} \text { test }\right. \\
\text { with Yates correction) }\end{array}$ & & \\
\hline & & & $\begin{array}{l}\text { Dietary intakes marginal } \\
\text { deficiency }(<2 / 3 \mathrm{RDA}) \text { of } \\
\text { vitamin } \mathrm{B}_{3} \text { by } 3-\mathrm{d} \text { record }\end{array}$ & & & $\begin{array}{l}\text { N.S. }\left(X^{2} \text { test with Yates }\right. \\
\text { correction })\end{array}$ & & \\
\hline
\end{tabular}

${ }^{1}$ values compared highest vs. lowest percentile, ${ }^{2}>10 \%$ sites with CAL $>4 \mathrm{~mm} \&>10 \%$ sites PPD $>3 \mathrm{~mm},{ }^{3}>1$ site with BOP. Abbreviations: $95 \% \mathrm{CI}$ : $95 \%$ confidence interval, BOP: bleeding on probing; CC: Case-control study, CPI: Community periodontal index, CS: cross-sectional study, d: days, mult.: multiple, N: sample size, N.S.: not significant, NHANES: National Health and Nutrition examination Survey, OR: Odds ratio, Ref: reference, reg.: regression, RPI: Russel's Periodontal Index, RDA: recommended dietary amount, US: United States, vs.: versus, y: years. 


\subsection{Vitamin C}

Vitamin C, also known as L-ascorbic acid, acts as enzymatic cofactor in a range of essential metabolic reactions as ascorbate $[66,67]$. These include hydroxylation of proline and lysine which is needed to stabilize its collagen structure during its manufacture. This activity confers to vitamin $\mathrm{C}$ a key role in the maintenance of the integrity of connective tissues such as the periodontium.

Actually, it is well known that vitamin C deficiency causes scurvy, but it is not certain whether milder degrees of insufficiency have clinically important effects on the periodontium. Furthermore this nutrient is involved in immunological functions, such as phagocytosis, and in wound healing. Vitamin $\mathrm{C}$ insufficiency may affect immunocompetence. Moreover, ascorbic acid is also known as a powerful antioxidant in living organisms, particularly at intracellular level [67]. A function in which some enzyme-dependent systems cooperate recycling oxidized forms. All these functions and activities have conferred to vitamin $\mathrm{C}$ an interesting potential role in periodontal health. Probably, this explains why this nutrients has been the most studied among all vitamins in relation to periodontal disease. Actually, the research into the relationship between vitamin $C$ and periodontal-related diseases comes from as far as the eighteenth century when it was observed that scurvy was fully recovered after a treatment with oranges and lemons [68]. Since then, many experimental (Table 5) and epidemiological studies have tried to address the relationship between vitamin $C$ and periodontal disease. In fact, a total of 14 reports have been selected for this review in relation to this topic. This makes this vitamin the most represented.

Studies in animal models have been performed on male rats [57,58], in which periodontitis was experimentally induced by placing ligature around some teeth and the effects of vitamin C-supplemented diets were compared with standard diets. Overall, results from them endorse the protective or therapeutic role of vitamin $C$ on periodontal health. After disease development by the mentioned procedure, vitamin $C$ showed to improve bone density index (BDI) at areas with periodontitis [58]. In relation to bone metabolism markers, the supplemented diet decreased RANKL expression suggesting that osteoclastogenesis stimulation is diminished despite an increase in alkaline phosphatase (AP) was also observed [58]. The analysis of additional markers has shown that consumption of vitamin C-supplemented diets improved the values of some oxidative stress markers (reduced glutathione (GSH) to oxidized glutathione (GSSG) ratio and 8-hydroxydeoxyguanosine (8-OhdG)) [57], decrease myeloperoxidase (MPO) activity [43] and down-regulated the expression of assessed pro-inflammatory cytokines (interleukin (IL)-1 $\alpha$ and IL-1 $\beta$ ) [57]; all associated to experimental periodontitis.

In regard to research in humans, 15 observational studies and six randomized-controlled trials (RCT) were found among the selected studies. Results from observational studies are contradictory and often depend on parameter evaluated. Concerning dietary intake, several studies have reported a negative association with periodontal disease. Among cross-sectional studies, one of most interesting evidences are provided by Nishida et al. [69] who reported a dose-dependent relationship between vitamin $C$ intake and the number of persons with periodontitis (defined by an average value of CAL of $1.5 \mathrm{~mm}$ or higher) in a sample of 12,419 NHANES III participants. Otherwise, no relationships have been found in other investigations. These included a cross-sectional study in 80 patients from a U.S. dental clinic [21] already cited for previous vitamins and a case-control study in 42 patients from an academic center in The Netherlands [70], but also a cross-sectional study in 3043 participants from Japanese NHANES [65] where periodontitis was defined by a CPI of 3 or more. In the same sense, in the study above that compared female adolescent with and without gingivitis [37] no differences were observed in relation to prevalence of marginal deficiency of vitamin $C$ intake.

In contrast, those studies evaluating vitamin $C$ levels in blood mostly supported a negative association between nutritional status and periodontal disease. Among them, there was a cohort study in a younger group of Indonesian villagers reporting a negative correlation between plasma vitamin $C$ level and CAL after 15 years [71]. Additionally, participants with vitamin C deficiency displayed higher CAL than those with no depletion or normal plasma values [71]. Likewise, case-control studies also 
confirmed this association [70,71]. Among them, one where authors subdivided periodontitis patients into systemically healthy subjects and those type 2 diabetes mellitus (DM2) patients [72]. However, these last results may be questioned because the report did not offer details about possible pair-matched, confounding analysis or prevention of detection bias. Interestingly, the other case-control study, cited above [70], did not find significant association with dietary intakes. In turn, in the cross-sectional study in dental clinic patients [36] did not find associations with RPI as occurred with dietary intakes. Still, vitamin C levels were negatively associated with periodontitis prevalence in other study based on the NHANES III data, previously mentioned [38]. Furthermore, this association was significant depending on periodontitis definition criteria. Despite many studies reported an absence of association between vitamin $C$ and periodontitis, it is important to note that those based in great and representative samples did it. Moreover, there was a wide variety in these studies concerning definitions and periodontal health-related clinical parameters used, which could explain in part the differences found among their results. On the other hand, some epidemiological studies have also focused on antibody levels against certain microorganism negatively related to periodontal health. In one of this, plasma concentrations of vitamin $C$ were inversely correlated with the number of oversensitive to P. gingivalis [73]. On the other hand, when total immunoglobulin G (IgG) levels to several oral bacteria were taken into account, there was no association with dietary intakes of vitamin $C$ in a sub-cohort aged 35-70 years old from the European Prevalence of Infection in Intensive Care Study [74]. This suggest that P. gingivalis is particularly interesting for periodontal disease pathogenesis.

Moreover, dietary vitamin $C$ effects in the presence of typical risk factors also have been evaluated. Among others, the possible interaction with smoking has been evaluated in studies restricted to a particular subgroup or by means of stratification. In the study by Nishida et al. [69] with NHANES III data from current and former smoker subjects, a dose-dependent relationship between vitamin C intake and periodontal disease diagnosis was reported, being stronger in current smokers. However, serum levels were negatively associated with periodontitis prevalence in other study based also on NHANES III data when only never-smokers were included, even after used a more restrictive criteria to define periodontitis [38]. Similarly, studies stratified by age or restricted to elderly people have been performed. Two cohort studies restricted to old segment of population have provided evidences for negative associations among disease and vitamin $C$ intake. In a subset of 73 years old subjects from Niigata study, the number of teeth with periodontal disease progression for 2 years of follow-up was shown to be inversely affected by vitamin $C$ intake, even after adjustment for potential confounder [34]. Aged subjects from the same survey showed similar associations when follow-up time was of 8 years [75]. In a cross-sectional study, elderly participants from Niigata city (Japan) exhibited a weak negative association although significant among CAL and serum vitamin C levels, even after adjustment for potential confounders in multivariate regression analysis [61]. Curiously, in a stratified cohort study in Americans that participated in the first National Health and Nutrition Examination Survey (NHANES I) and NHANES I Epidemiologic Follow-up Study (NHEFS) with a follow-up of approximately 10 years in a population of all ages, an inverse relationship with dietary intake was noted but only in younger persons (25-59 years) [76]. Therefore, although age and smoking can be related with efficacy of vitamin for periodontal disease prevention, this can depend on population features. In addition, results from a study in rats also have suggested that vitamin $C$ supplementation could contribute to prevent the effect of other nutritional risk factors associated with this disease, namely cholesterol amount in the diet, on alveolar bone density [59]. This effect was also associated to a decrease in osteoclast differentiation markers and serum 8-OHdG initiating that it act by mechanisms related to oxidative stress and osteoclastogenesis regulation as occurred in similar models fed standard diets $[57,58]$. All these suggest that vitamin $C$ also can contributed to prevent the effect of other risk factors of periodontal health the use of supplements could result particularly interesting for subjects showing such risks. 
Table 5. Observational studies on vitamin $C$ association with periodontal disease.

\begin{tabular}{|c|c|c|c|c|c|c|c|c|}
\hline $\begin{array}{l}\text { Study } \\
\text { Type }\end{array}$ & Sample & Sex; Age; N & $\begin{array}{l}\text { Dietary Intake } \\
\text { Assessment }\end{array}$ & $\begin{array}{l}\text { Nutritional Status } \\
\text { Assessment }\end{array}$ & Periodontal Status & Analysis Results ( $p$-Value) & Main Results/Conclusions & Ref \\
\hline \multirow{2}{*}{ CS } & \multirow{2}{*}{$\begin{array}{l}\text { NHANES III } \\
\text { Participants (US) }\end{array}$} & \multirow{2}{*}{$\begin{array}{l}\text { Both; } \leq 20 \mathrm{y} \\
\mathrm{N}=12,419\end{array}$} & \multirow{2}{*}{$\begin{array}{c}\text { Dietary intake by } \\
\text { 24-h recall }(0-29, \\
30-59,60-99 \\
100-179, \& \geq 180 \mathrm{mg})\end{array}$} & \multirow[t]{2}{*}{ 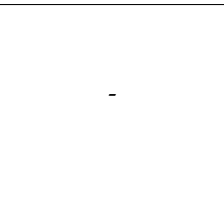 } & \multirow{2}{*}{ Periodontal disease $^{3}$} & $\begin{array}{l}\left.\mathrm{OR}^{1}=1.28 \text { (95\%CI: } 1.02-1.43\right) ; \\
p<0.05 \text { for trend (mult. logistic } \\
\text { reg.) in current smokers }\end{array}$ & \multirow{2}{*}{$\begin{array}{l}\text { Negative association in } \\
\text { smokers, it was stronger in } \\
\text { former smokers than current } \\
\text { tobacco users }\end{array}$} & \multirow{2}{*}{ [69] } \\
\hline & & & & & & $\begin{array}{l}\mathrm{OR}^{1}=1.21 \text { (95\%CI: 102-1.43); } \\
p<0.05 \text { for trend (mult. logistic } \\
\text { reg.) in former smokers }\end{array}$ & & \\
\hline \multirow{4}{*}{ CS } & \multirow{4}{*}{$\begin{array}{l}\text { NHANES III } \\
\text { participants (US) }\end{array}$} & \multirow{4}{*}{$\begin{array}{l}\text { Both; } \leq 20 \mathrm{y} \\
\mathrm{N}=11,480\end{array}$} & \multirow{4}{*}{-} & \multirow{4}{*}{$\begin{array}{l}\text { Serum levels } \\
\text { (quintiles) }\end{array}$} & Mild periodontitis 4 & $\begin{array}{c}\left.\mathrm{OR}^{2}=0.82 \text { (95\%CI: } 0.76-0.87\right) ; \\
p=0.0001 \text { (mult. logistic reg.) in } \\
\text { non-restricted model }\end{array}$ & \multirow{4}{*}{$\begin{array}{l}\text { Negative association, it was } \\
\text { stronger with severe disease, } \\
\text { \& in never-smokers }\end{array}$} & \multirow{4}{*}{ [38] } \\
\hline & & & & & & $\begin{array}{l}\mathrm{OR}^{2}=0.71 ;(95 \% \text { CI: } 0.58-0.86) \\
p=0.001 \text { for trend (mult. logistic } \\
\text { reg.) in model restricted to } \\
\text { never-smokers }\end{array}$ & & \\
\hline & & & & & \multirow{2}{*}{ Severe periodontitis ${ }^{5}$} & $\begin{aligned} \mathrm{OR}^{2} & =0.76 \text { (95\%CI: } 0.69-0.84) \\
p & =0.0001 \text { for trend) in } \\
& \text { non-restricted model }\end{aligned}$ & & \\
\hline & & & & & & $\begin{array}{c}\mathrm{OR}^{2}=0.8(95 \% \mathrm{CI}: 0.71-0.89) ; \\
p=0.0001 \text { for trend (mult. logistic } \\
\text { reg.) in model restricted to } \\
\text { never-smokers }\end{array}$ & & \\
\hline CS & $\begin{array}{c}\text { Niigata study } \\
\text { participants (Japan) }\end{array}$ & Both; $70 \mathrm{y} ; \mathrm{N}=413$ & - & Serum levels & CAL & $\begin{array}{c}\beta=-0.04 \text { (95\%CI: }-0.06 \text { to } \\
-0.005) ; p<0.05 \text { (mult. linear reg.) }\end{array}$ & Negative association & [77] \\
\hline CS & $\begin{array}{l}\text { Dental clinic } \\
\text { patients (US) }\end{array}$ & Both; N.A.; N = 80 & $\begin{array}{l}\text { Dietary intakes by } \\
24-\mathrm{h} \text { recall }\end{array}$ & Serum levels & RPI & $\begin{array}{c}\text { N.S. (mult. linear reg with } R^{2} \\
\text { improvement) }\end{array}$ & No associations & [36] \\
\hline CS & $\begin{array}{c}\text { NHANES } \\
\text { participants (Japan) }\end{array}$ & $\begin{array}{l}\text { Both; } \geq 20 \mathrm{y} \\
\mathrm{N}=3043\end{array}$ & $\begin{array}{l}\text { Dietary intake by } \\
24-\mathrm{h} \text { recall }\end{array}$ & - & $\mathrm{CPI}=3-4$ & N.S. (mult. logistic reg.) & No associations & [65] \\
\hline \multirow{2}{*}{ CS } & \multirow{2}{*}{$\begin{array}{c}\text { Men from 2 } \\
\text { populations } \\
\text { (Finland \& Russia) }\end{array}$} & \multirow{2}{*}{$\begin{array}{c}\text { Male; } 48.2 \pm \\
13.6 / 44.8 \pm 11.4 \mathrm{y} ; \mathrm{N} \\
=431\end{array}$} & \multirow[t]{2}{*}{ - } & \multirow{2}{*}{ Plasma levels } & Serum IgG against Pg & $\begin{aligned} \mathrm{r}=- & -0.22 ; p<0.001 \text { (Pearson } \\
& \text { correlation analysis) }\end{aligned}$ & \multirow{2}{*}{$\begin{array}{l}\text { Negative association with } \\
\text { anti-Pg IgGs level }\end{array}$} & \multirow{2}{*}{ [73] } \\
\hline & & & & & $\begin{array}{c}\text { Serum IgG against } \\
\text { Agact }\end{array}$ & N.S. (Pearson correlation analysis) & & \\
\hline CS & $\begin{array}{l}\text { Cancer-free } \\
\text { individuals from an } \\
\text { EPIC sub-cohort } \\
\text { (Europe) }\end{array}$ & $\begin{array}{l}\text { Both; } 35-70 \text { y; } \\
\quad \text { N = } 395\end{array}$ & Dietary intake * & - & $\begin{array}{l}\text { Total IgGs levels for } 25 \\
\quad \text { oral bacteria }{ }^{6}\end{array}$ & N.S. (generalized linear models) & No association & [74] \\
\hline CC & $\begin{array}{c}\text { Non-smokers } \\
\text { outpatients (India) }\end{array}$ & Both; 30-60 y; $N=60$ & - & Serum levels & $\begin{array}{c}\text { DM2 \& periodontal } \\
\text { disease-affected7 only } \\
\text { periodontal } \\
\text { disease-affected \& } \\
\text { healthy }\end{array}$ & $\begin{array}{l}0.93( \pm 0.24)>0.335( \pm 0.5)>0.292 \\
( \pm 0.004) ; p<0.001 \text { (student } t \text { test) }\end{array}$ & $\begin{array}{c}\text { Subjects with periodontal } \\
\text { disease showed lower vitamin } \\
\text { C levels }\end{array}$ & [72] \\
\hline
\end{tabular}


Table 5. Cont.

\begin{tabular}{|c|c|c|c|c|c|c|c|c|}
\hline $\begin{array}{l}\text { Study } \\
\text { Type }\end{array}$ & Sample & Sex; Age; N & $\begin{array}{l}\text { Dietary Intake } \\
\text { Assessment }\end{array}$ & $\begin{array}{l}\text { Nutritional Status } \\
\text { Assessment }\end{array}$ & Periodontal Status & Analysis Results ( $p$-Value) & Main Results/Conclusions & Ref \\
\hline \multirow{3}{*}{ CC } & \multirow{2}{*}{$\begin{array}{l}\text { Patients from an } \\
\text { academic center } \\
\text { (NL) }\end{array}$} & \multirow[b]{2}{*}{ Both; $\geq 21 \mathrm{y} ; \mathrm{N}=42$} & - & Levels in plasma & \multirow{2}{*}{$\begin{array}{l}\text { Periodontitis-affected }{ }^{8} \\
\text { vs. healthy }\end{array}$} & $\begin{array}{c}8.3( \pm 3.9)<11.3( \pm 5.2) \mathrm{mg} / \mathrm{L} ; \\
p=0.03 \text { (N.A.) }\end{array}$ & \multirow{2}{*}{$\begin{array}{l}\text { Subjects with periodontitis } \\
\text { showed lower plasma levels } \\
\text { of vitamin C }\end{array}$} & \multirow[b]{2}{*}[70]{} \\
\hline & & & $\begin{array}{l}\text { No. of servings (of } \\
\geq 31,30 \text { to } 2 \text {, or }<2 \\
\text { mg per } 100 \mathrm{mg} \text { ) by } \\
\text { 3-d record }\end{array}$ & & & N.S. differences & & \\
\hline & \multirow[b]{3}{*}{$\begin{array}{l}\text { Non-smokerss } \\
\text { adolescents (Italy }\end{array}$} & \multirow[b]{3}{*}{$\begin{array}{l}\text { Female; } 17-19 \mathrm{y} \\
\qquad \mathrm{N}=56\end{array}$} & $\begin{array}{l}\text { Total intake by 3-d } \\
\text { record }\end{array}$ & & & N.S. differences & & \\
\hline \multirow[b]{2}{*}{$\mathrm{CC}$} & & & $\begin{array}{l}\text { Dietary intake by } \\
\text { 3-d record }\end{array}$ & & \multirow[b]{2}{*}{$\begin{array}{l}\text { Gingivitis affected }{ }^{9} \text { vs. } \\
\text { non-affected }\end{array}$} & N.S. differences (Student $t$ test) & \multirow[b]{2}{*}{ No association } & \multirow[b]{2}{*}[37]{} \\
\hline & & & $\begin{array}{c}\text { Dietary intakes } \\
\text { marginal deficiency } \\
(<2 / 3 \text { RDA) by 3-d } \\
\text { record }\end{array}$ & - & & N.S. differences ( $X^{2}$ test $)$ & & \\
\hline $\mathrm{RC}(2 \mathrm{y})$ & $\begin{array}{c}\text { Niigata study } \\
\text { participants (Japan) }\end{array}$ & Both; 73 y; $N=264$ & $\begin{array}{c}\text { Dietary intake } \\
\text { (tertiles) by BDHQ }\end{array}$ & - & $\begin{array}{l}\text { No. of teeth with } \\
\text { periodontal disease } \\
\text { progression }{ }^{10}\end{array}$ & $\begin{array}{c}\left.\text { IRR }^{2}=0.72 \text { (95\%CI: } 0.56-0.93\right) ; \\
p<0.05 \text { for trend (mult. } \\
\text { logistic reg.) }\end{array}$ & Negative association & [41] \\
\hline $\mathrm{C}(8 \mathrm{y})$ & $\begin{array}{c}\text { Niigata study } \\
\text { participants (Japan) }\end{array}$ & Both; 71 y; N = 224 & - & $\begin{array}{l}\text { Serum levels } \\
\text { (tertiles) }\end{array}$ & $\begin{array}{l}\text { Periodontal disease } \\
\text { events }{ }^{11}\end{array}$ & $\begin{array}{c}\left.\mathrm{RR}^{2}=1.30 \text { (95\%CI: } 1.16-1.47\right) \\
p<0.05 \text { for trend (mult. } \\
\text { logistic reg.) }\end{array}$ & Negative association & [77] \\
\hline $\mathrm{RC}(3 \mathrm{y})$ & $\begin{array}{c}\text { Residents from a } \\
\text { village (Indonesia) }\end{array}$ & $\begin{array}{l}\text { Both; } 33-43 \text { y; } \\
\quad \mathrm{N}=123\end{array}$ & - & $\begin{array}{c}\text { Plasma levels (>2; } \\
2-3.9 ; \text { or } \geq 4.0 \mathrm{mg} / \mathrm{L})\end{array}$ & Mean CAL & $\begin{array}{c}\beta=-0.199 ; p=0.029 \text { (mult. } \\
\text { linear reg.) }\end{array}$ & Negative association & [72] \\
\hline \multirow{2}{*}{$\mathrm{C}(10 \mathrm{y})$} & \multirow{2}{*}{$\begin{array}{l}\text { NHEFS \& NHANES } \\
\text { I participants (US) }\end{array}$} & \multirow{2}{*}{$\begin{array}{l}\text { Both; } 25-74 \mathrm{y} \\
\mathrm{N}=10,523\end{array}$} & \multirow{2}{*}{$\begin{array}{l}\text { Dietary intake (\% } \\
\text { NHANES standards) } \\
\text { by } 24-\mathrm{h} \text { recall \& FFQ }\end{array}$} & \multirow{2}{*}{ - } & \multirow{2}{*}{ Total teeth lost } & $\begin{array}{l}\beta=-0.0031( \pm 0.0011) ; p=0.01 \\
\text { (mult. linear reg.) in 25-59 y old } \\
\text { subjects }\end{array}$ & \multirow{2}{*}{$\begin{array}{l}\text { Negative association only in } \\
\text { younger subjects }\end{array}$} & \multirow{2}{*}[76]{} \\
\hline & & & & & & $\begin{array}{l}\text { N.S. (mult. linear reg.) in 60-74 y } \\
\text { old subjects }\end{array}$ & & \\
\hline $\begin{array}{l}{ }^{1} \text { val } \\
\text { with } \\
\text { ATC } \\
\text { nigre } \\
\text { ATC } \\
7073 \\
\text { Abbi } \\
\text { stud } \\
\text { mell } \\
\text { of Pe } \\
\text { Surv } \\
\text { PMI } \\
{ }^{*} \text { by }\end{array}$ & $\begin{array}{l}\text { es compared lowest v } \\
\text { 25L } \geq 5 \text { mm \& } 1 \text { mes } \\
\text { cens ATCC 335636, Ve } \\
\text { 29212, Parvimonas m } \\
\text { generalized CAL } \geq \\
\text { viations: 95\%CI: } 95 \% \\
\text { CEJ: Cementum-em } \\
\text { ds type 2, FBG: Fastin } \\
\text { iodontal Diseases \& } \\
\text {; NHEFS: NHANES } \\
\text { Polymorphonuclear } \\
\text { tensive quantitative }\end{array}$ & $\begin{array}{l}\text { highest percentile, } \\
\text { buccal sites with PF } \\
\text { periodontium ATCC } \\
\text { lonella atypica ATC } \\
\text { a ATCC 33270, Pept } \\
\text { mm \& BOP, } 8 \text { ABL > } \\
\text { onfidence interval, } \\
\text { nel junction, CS: cro } \\
\text { blood glucose, FFQ } \\
\text { onditions in 1999, I } \\
\text { Epidemiologic Follo } \\
\text { eutrophils, PPD: Per } \\
\text { ietary questionnair }\end{array}$ & $\begin{array}{l}\text { values compared hig } \\
\geq 4 \text { mm, }{ }^{2} \text { Pg ATCC } \\
3693 \text {, Fusobacterium } p \\
\text { 17744, Veillonella parz } \\
\text { treptococcus anaerobiu } \\
\text { /3 of the root length } \\
\text { gact: Aggregatibacter a } \\
\text {-sectional study, EPI } \\
\text { ood frequency quest } \\
\text { HANES I: First Natic } \\
\text {-up Stud, NL: Nethe } \\
\text { dontal probing deptl } \\
\text { or semi-quantitative }\end{array}$ & $\begin{array}{l}\text { est vs. lowest percen } \\
33277 \text { \& ATCC } 53978 \\
\text { lymorphum ATCC } 10 \\
\text { ula ATCC 10790, Bifid } \\
\text { ATCC 27337, Strepto } \\
\mathrm{n}>1 \text { tooth per quadr } \\
\text { tinomycetemcomitans, } \\
\text { : : European Prospec } \\
\text { onnaire, IgG: Immun } \\
\text { nal Health and Nutr } \\
\text { lands, OR: Odds ratic } \\
\text {; RBG: Random bloo } \\
\text { FFQ or combined foc }\end{array}$ & $\begin{array}{l}\text { le, }{ }^{3} \text { mean CAL } \geq 1.5 \mathrm{mr} \\
\text { Agact ATCC } 29523 \text { \& A } \\
53 \text {, Prevotella intermed } \\
\text { bacterium dentium ATCC } \\
\text { occus intermedius ATCC } 2 \\
\text { nt, }{ }^{9} \geq 1 \text { site with BOP, } \\
\text { 3OP: Bleeding on probin } \\
\text { ve Investigation into Ca } \\
\text { globulin G, IRR: Inciden } \\
\text { ion Examination Surve } \\
\text { Pg: Porphyromonas gin } \\
\text { glucose, Russell's perio } \\
\text { d records \& questionnai }\end{array}$ & $\begin{array}{l}4 \geq 1 \text { site with CAL } \geq 4 \mathrm{~mm} \& \mathrm{P} \\
\text { CC } 43718, \text { Tannerella forsythia AT } \\
\text { ATCC 25611, Prevotella melan } \\
27534 \text {, Corynebacterium matruchot } \\
335 \text {, Streptococcus mitis ATCC } 49 \\
\text { CAL } \geq 3 \text { mm in } \geq 1 \text { site, } 11 \text { No. } \\
\text {; C: Cohort study, CAL: Clinical } \\
\text { eer and Nutrition, DM1: Diabe } \\
\text { e rate ratio, IWCPDC: Internatio } \\
\text { NHANES III: Third National } \\
\text { ivalis, PBMC: Peripheral blood n } \\
\text { ontal index; RR: Relative risk, U } \\
\text { s quartiles. }\end{array}$ & $\begin{array}{l}\mathrm{D} \geq 4 \mathrm{~mm},{ }^{5} \geq 2 \text { mesiobuccal } \\
\mathrm{C} 43037, \text { Fusobacterium nucle } \\
\text { ogenica ATCC 25845, Prevo } \\
\text { ATCC 14266, Enterococcus fa } \\
66 \text { \& Streptococcus salivarius A } \\
\text { teeth with a loss of CAL } \geq 3 \\
\text { ttachment level, CC: Case-co } \\
\text { s mellitus type 1, DM2: Dial } \\
\text { a Workshop for the Classific } \\
\text { ealth and Nutrition Examinc } \\
\text { ononuclear cells, PI: Plaque ir } \\
\text { Unite States, vs.: versus, y: y }\end{array}$ & \\
\hline
\end{tabular}


Despite evidences collected from animals and epidemiological studies, none intervention in humans presented here reported clear positive effects for vitamin $C$ supplementation on healthy subjects or periodontitis patients. Positive effects were noted only with increases of intakes through vitamin C-rich foods introduced on diet. Main finding supporting this idea comes from a cross-over trial where the same individuals chewed on sugar free gum contained vitamin $C$, non-vitamin $C$ and no gum for three months following by scaling treatment. Vitamin C-containing gum led to an improvement at gingival bleeding (GB) level, although interestingly, calculus score and visible plaque were diminished with the two gums. However, it is important to note that other clinical measurements related to periodontal disease like PPD or CAL were not taken, so treatment implications were not deeply known [53].

In relation to this parameters, another study, in this case in children, tested the effect of chewing on vitamin C enriched tablets on RPI but no effect were observed compared with mannitol-containing tablets that were used as placebo [54]. Notwithstanding, risk of performance bias was present because of variability in consumption. Likewise, no effects also was noted in other two investigations in patients that received root and planning therapy before a period of vitamin $C$ supplementation $[55,56]$. However, not blinding nor detail about selection comprised results in one of them. Problems in obtaining positive results could be due to used dosages or its combination with treatment more effective $[55,56]$ that may occult the effect of this nutrient. On the other hand, maybe correct vitamin $C$ intake is necessary to avoid periodontal problems but when the pathological state has been instituted, a supplementation with vitamin $C$ is not enough to revert it to the healthy state

\subsection{Vitamin $E$}

Vitamin E activity is exerted by a set of lipid-soluble food compounds featured by a phenolic-chromanol ring linked to an isoprenoid side chain. These are termed as tocopherols or tocotrienols depending on the phenolic-chromanol ring were saturated or unsaturated, respectively. In addition both can present four forms according to the number and position of methyl groups on the ring: $\alpha, \beta, \gamma$ and $\delta$ [78]. As expected, all these forms have been taken into account for this review. For this set of compounds, four observational studies in humans (Table 6) and two experimental studies in rats were found (Table 2). Regarding research in humans, there were two cohort studies and two cross-sectional studies. Serum levels of $\alpha$-tocopherol have been inversely associated with mean PPD and periodontitis (defined according to CDC/AAP criteria) in a subset of participants in the 1999-2001 NHANES. However, serum levels of $\gamma$-tocopherol showed a most modest association with subjects in the interquartile range displaying a significantly lower mean PPD than those in the highest quartile [3].

The rest of observational studies were restricted to elderly subjects [41,42,77]. Two cohort studies has provided complementary data supporting the positive effect of vitamin $\mathrm{E}$ on the prevention of periodontal disease progression (defined by an annual loss of CAL equal or higher than $3 \mathrm{~mm}$ or higher at any site over the study period) but they only were performed in elderly people. One of them, that have been previously reported [41], estimated dietary intakes of vitamin E [26] and the other evaluated serum levels of $\alpha$-tocopherol [77]. However, this survey could be affected by a possible detection bias due to self-assessment and no inclusion of supplement as we pointed out previously. In contrast, no association of periodontitis with $\alpha$-tocopherol or $\gamma$-tocopherol levels was found in PRIME study participants [42], although it was a cross-sectional study. Anyway, both studies reporting associations were performed with subjects form Niigata city (Japan), it would be interesting evaluate this relationship in cohorts from other population to validate this association, at least in old people. 
Table 6. Observational studies on vitamin E association with periodontal disease.

\begin{tabular}{|c|c|c|c|c|c|c|c|c|}
\hline $\begin{array}{l}\text { Study } \\
\text { Type }\end{array}$ & Sample & Sex; Age; N & $\begin{array}{c}\text { Dietary Intake } \\
\text { Assessment }\end{array}$ & $\begin{array}{c}\text { Nutritional Status } \\
\text { Assessment }\end{array}$ & Periodontal Status & Analysis Results ( $p$-Value) & $\begin{array}{c}\text { Main } \\
\text { Results/Conclusions }\end{array}$ & Ref \\
\hline \multirow{6}{*}{ CS } & \multirow{6}{*}{$\begin{array}{l}\text { 1999-2001 NHANES } \\
\text { participants (US) }\end{array}$} & \multirow{6}{*}{$\begin{array}{c}\text { Both; adults } \\
\mathrm{N}=4708\end{array}$} & \multirow{6}{*}{ - } & \multirow{3}{*}{$\begin{array}{l}\text { Serum levels of } \\
\alpha \text {-tocopherol adjusted by } \\
\text { cholesterol levels } \\
\text { (quartiles) }\end{array}$} & mean PPD & $\begin{array}{c}\text { Mean }^{1}=1.07 \text { (95\%CI: } \\
1.00-1.15) ; 0.96 \text { ( } 95 \% \text { CI: } 0.90 \\
1.02) p=0.005 \text { for trend (mult. } \\
\text { logistic reg.) }\end{array}$ & \multirow{6}{*}{$\begin{array}{l}\text { Non-linear inverse } \\
\text { association of } \\
\alpha \text {-tocopherol levels } \\
\text { with mean PPD \& } \\
\text { periodontitis }\end{array}$} & \multirow{6}{*}{ [3] } \\
\hline & & & & & CAL & N.S. (mult.logistic reg.) & & \\
\hline & & & & & Periodontitis $^{3}$ & $\begin{array}{c}\left.\mathrm{OR}^{1}=1.65 \text { (95\%CI: } 1.26-2.16\right) \\
p=0.005 \text { for trend (mult. } \\
\text { logistic reg.) }\end{array}$ & & \\
\hline & & & & \multirow{3}{*}{$\begin{array}{c}\text { Serum levels of } \\
\gamma \text {-tocopherol adjusted by } \\
\text { cholesterol levels } \\
\text { (quartiles) }\end{array}$} & CAL & N.S. (mult.logistic reg.) & & \\
\hline & & & & & mean PPD & N.S. (mult.logistic reg.) & & \\
\hline & & & & & Periodontitis $^{3}$ & N.S. (mult.logistic reg.) & & \\
\hline \multirow[t]{2}{*}{ CS } & \multirow[t]{2}{*}{$\begin{array}{l}\text { PRIME participants } \\
\text { (Northern Ireland) }\end{array}$} & \multirow{2}{*}{$\begin{array}{l}\text { Male; } 60-70 \mathrm{y} ; \\
\quad \mathrm{N}=1258\end{array}$} & \multirow[t]{2}{*}{-} & \multirow{2}{*}{$\begin{array}{c}\text { Serum levels of } \\
\alpha \text {-tocopherol \& } \\
\gamma \text {-tocopherol (quintiles) }\end{array}$} & $\begin{array}{l}\text { Low-threshold }^{4} \\
\text { Periodontitis }\end{array}$ & N.S. (mult.logistic reg.) & \multirow[t]{2}{*}{ No associations } & \multirow[t]{2}{*}{ [42] } \\
\hline & & & & & $\begin{array}{c}\text { High-threshold }{ }^{5} \\
\text { periodontitis }\end{array}$ & N.S. (mult.logistic reg.) & & \\
\hline $\mathrm{C}(8 \mathrm{y})$ & $\begin{array}{c}\text { Niigata study } \\
\text { participants (Japan) }\end{array}$ & Both; 71 y; N = 224 & - & $\begin{array}{c}\text { Serum levels of } \\
\alpha \text {-tocopherol (tertiles) }\end{array}$ & $\begin{array}{l}\text { Periodontal disease } \\
\text { events }^{6}\end{array}$ & $\begin{array}{c}\left.\mathrm{RR}^{2}=1.15 \text { (95\%CI: } 1.04-1.28\right) ; \\
p<0.05 \text { for trend } \\
\text { (mult.logistic. reg.) }\end{array}$ & Negative association & [75] \\
\hline
\end{tabular}


Because of their liposoluble properties, vitamin $\mathrm{E}$ is able to incorporate in biological membranes where it inhibits peroxidation of lipids [79,80] due to this well-known antioxidant activity [80]. As consequence, vitamin E stops the production of ROS formed when fat undergoes oxidation [78] preventing propagation of damage to cell membranes by peroxyl radicals formed by the oxidation of lipids to stabilize the membrane structure by terminating the free radical chain reaction [78-80]. Research in animals has allowed to evaluate the use of vitamin E supplements on periodontal diseases and its possible role on ROS and inflammatory processes associated with this conditions [46,47]. In a rat model of periodontitis induced by ligatures, vitamin E supplements prevented increases in malondialdehyde levels and immunoreactivity to inducible nitric oxide synthase (iNOS), but did not decrease ABL [61]. However, in other rats stressed on a rotational device or not stressed, supplements had a protective effect on bone loss in all cases, but there was no interaction with stress condition [62]. Therefore, experiments in rats suggest that vitamin E supplements would prevent oxidative stress associated to periodontitis [46,47], but its potential for periodontal disease treatment is not clear since they did not decreased ABL always [46]. In any case, there are no studies evaluating its possible use as nutraceutical in relation to this disease in humans.

\section{Materials and Methods}

\subsection{Selection Criteria}

Inclusion and exclusion criteria for the selection of papers to be reviewed were established prior to commencement of the literature search. For this review, researches using both humans and animals were included, but only written in English language. All relevant studies investigating the association between periodontal disease and nutrient dietary intake or nutritional status markers were included, even if they focused only on people belonging to certain age groups or on subjects with any special physiological condition or illness (pregnancy, menopause, diabetes mellitus or others). Studies had to assess periodontal health condition, including also number of teeth or edentulism. However it was considered that it could be due to other pathologies. Regarding study design, cross-sectional, cohort and case-control studies were selected within those belonging to observational type. On the other hand, only RCT were accepted from experimental surveys collected. Additionally, interventional trials with nutrient combinations were excluded for individual assessment of each nutrient, although some exceptions were made, which will be discussed later. Similar exclusion criteria were used in the case of animal studies.

\subsection{Information Source and Search Terms}

The electronic database of the National Library of Medicine (Washington, DC, USA) (MEDLINE: PubMed) was used to select appropriate papers. We first derived two themes that were then combined by using the Boolean operator "AND". Each theme was created by using the operator "OR" to search for terms appearing as either explorer text words or Medical Subjects Headings (Mesh), when they existed and it was not contained within other, also used. The selected periodontal disease related terms were: periodontal, periodontitis, gingivitis and it was also included the following outcome measurement related to periodontal disease: "Alveolar Bone Loss" [Mesh] OR "Periodontal Diseases" [Mesh] OR "Periodontal Attachment Loss" [Mesh] OR "Periodontal Index" [Mesh] OR "Gingival Hemorrhage" [Mesh] OR "periodontal disease" OR periodontitis OR "alveolar bone loss" OR "alveolar bone resorption" OR "tooth attachment" OR "tooth mobility" OR "gingivitis" OR "clinical attachment level" OR "periodontal attachment level" OR "attachment loss" OR "periodontal pocket" OR "pocket depth" OR "probing depth" OR "bleeding on probing" OR "gingival bleeding" OR "Gingival Hemorrhage" OR "gingival index" OR "bleeding index" OR "periodontal index". In addition to this, a second theme related to nutrition or diet was created. Search terms were as follows: "Food" [Mesh] OR "Diet" [Mesh] OR "Eating" [Mesh] OR "Nutrition Surveys" [Mesh] OR "Nutrition Assessment" [Mesh] OR “Nutrition Therapy" [Mesh] OR “Nutrition Processes" [Mesh] OR 
"Nutritional Status" [Mesh] OR nutrition * OR nutrition OR nutrient * OR nutrient OR food OR dietary OR diet * OR intake OR intakes OR consumption* OR consumption OR ingestion OR eating. Finally, for each nutrient it was combined with all name synonyms, its precursors and its ionic forms present in organism as search terms.

\subsection{Search Strategy}

The search strategy aimed to find both published studies in the English language from the inception of the database until February 2018. A comprehensive literature search was run independently by two of the review authors. At first, papers were screened by title and abstract. Screening procedures were adjusted for higher sensitivity (with restrictive search items omitted). Secondly, full text-papers were retrieved and selected based on the eligibility criteria, and duplicated studies were excluded. Titles without abstract but which suggested that they were related to the objectives of this review were selected for full text screening to screen the full text. Inconveniently, our methodological approach did not allow to obtain articles nor available on line, or published in journals whose rights had not been acquired by University of Granada at the date of search. Review authors' disagreements or inconsistencies concerning inclusion of publications or extraction of data were discussed to eventually achieve mutual consensus.

\subsection{Data Collection Process, Data Items and Summary Measures}

The quantitative data extracted from papers included specific details about the interventions, populations, study methods, and significant outcomes for the review question and specific objectives. Data from eligible studies were independently evaluated. When they were available, outcome measurement means or differences between means, and their standard deviations between groups like clinical outcomes for periodontal disease, nutritional status or dietary intakes, depending on study, were included in our description of the results. In the same way, association measurements, such as correlation or regression coefficients, IRRs, ORs, RRs, HRs and their corresponding 95\% CI, as well as significance levels considered or $p$-values were considered, but only if significant associations and/or differences were found.

\subsection{Quality Assessment and Risk of Bias}

Subsequently, potentially relevant publications were read in full to determine their quality, mainly through the assessment of bias risk. The methodological quality of a publication was determined in accordance with several criteria depending on the study design. For observational studies, evaluation and strategies to deal with them were considered in addition to risk of bias. According to the prevention of confounding effects, the employment of randomization, only in clinical trials, matching or restriction, were explored at design level, while the use of multivariate analysis, stratification or frequency matching was appraised at data analysis level. Concerning the risk of bias, four types of bias have been proposed: selection, detection, attrition and reporting bias [81]; although other authors have simplified this classification into two categories: selection and information bias [82]. Anyway, critical issues for prevent them present differences among design types. For cross-sectional studies, three points were mainly evaluated: sample randomization, reliability and objectivity of variables assessment, as well as definition of group if comparisons were made. For case-control studies, it was also taken into account the objectivity and reliability of subjects evaluations including here category definitions and exposure evaluation methods. Lastly, for cohort studies, it was considered the exposure and status definition and measurement. In the same way, differences in duration, reliability and objectivity of outcome assessment were considered. Also, the presence of differences on intensity of medical surveillance, loss of follow-up, missing data treatment, and differences related to the outcome or exposure of risk factors between those who drop out and those who stay in the study were taken into account. Inclusion criteria and/or sources of data or individuals background were considered for the establishing of the sample external validity and set of population represented. Additionally, 
grouping criteria in data analysis were account, when they were presented, especially if they were selected post hoc from alternative options.

On the other hand, Intervention trials were assessed according to Cochrane guidelines, which take into account five type of bias: selection, performance, detection, attrition and reporting bias [83]. Based on their recommendations, the following domains were evaluated: sequence generation (randomization), allocation concealment, blinding of participants, operators and/or examiners, incomplete outcome data and selective reporting. In function of the results of this assessment, degree of risk (high, low or unclear) was established for each type of bias, as well as its possible magnitude and direction. The risk of bias and its possible effects were summarizing for each outcome within each study. Finally, it was summarized for review as a whole, where it was possible.

\section{Conclusions}

The aim of this review was to analyze the main published data until February 2018 on the relationship between vitamins and the development and progression of periodontal disease both in humans and animals to understand the potential benefits and risks of supplementation with vitamins on this pathology. Although some studies suggest that improving or maintaining an optimal nutritional status in relation to vitamins, particularly for vitamins D and C, in general, evidence supporting certain grade of relationship of vitamins with periodontal health is reduced and there are limitations that should be overcome. Among others, the number of experimental studies is reduced yet, particularly in humans; likewise, reported effects are usually too small to indicate the magnitude of therapeutic supplements, even when used as an adjunct to periodontal therapy. Importantly, for certain vitamins, interventions in humans did not reported clear positive effect despite evidence provided by observational and animal studies as occurred with vitamin $C$ supplementation. Concerning observational studies, the use of dietary supplement was ignored or normalized with the same value for all subjects in some of them. Moreover, there was a wide variety in observational studies concerning definitions and periodontal health-related clinical parameters used, which could explain in part the differences found among their results. In addition to that, few articles deepened on the mechanisms under the observed relationships. On the other hand, several studies have been performed on subgroups with conditions that represent a risk for bone health such as age, menopause or smoking status. The use of supplements could result particularly interesting for subjects showing such risks. For instance, different studies on vitamin D suggest that starting to take vitamin D supplementation from middle age could be particularly interesting for preventing periodontal disease advancement.

Problems in obtaining positive results from experimental studies could be due to used dosages or its combination with treatment more effective that may occult the effect of this nutrient. In spite of this, there is a paucity of well-designed, long-term experimental studies to ascertain the direct effects of dietary supplements on the outcomes on periodontal diseases. Therefore, the results and methodological approaches of many of the presented studies makes provided evidence no definitive to clearly consider as "nutraceutical" any of the vitamins included in this review. In this sense, is particularly important to note that supplementation is not enough to revert the periodontium to a healthy state, or at least at the moment there is not enough evidence supporting this. Therefore, the use of vitamin supplements in any case can replace other therapies. Notwithstanding, the use of supplements with several or certain vitamins for people under physiological or pathological conditions that increase the risk of suffers bone pathologies or pathological alterations could contribute to protect periodontal tissues. This suggests the existence of putative risk groups to recommend the consumption of nutraceutical in the context of periodontal health, but more studies are needed to confirm this and clarify what vitamins use for each case, as well as dosages and taking frequency.

Acknowledgments: Authors acknowledge to the University of Granada and the Autonomous Government of Andalusia for partial support of the research team. Francesca Giampieri was supported by a Fondazione Umberto Veronesi Fellowship. Alfonso Varela-López is recipient of a postdoctoral fellowship from the Foundation Alfonso Martin Escudero. María D. Navarro-Hortal has enjoyed a Research Initiation Scholarship for undergraduate 
students of the University of Granada's Own Plan during the 2016-2017 academic year and a Student Collaboration Grant for Research in University Departments for the academic year 2017-2018, from the Spanish Ministry of Education, Culture and Sports, 2017/2018 call.

Conflicts of Interest: The authors declare no conflict of interest.

\section{References}

1. Alagl, A.S.; Bhat, S.G. Ascorbic acid: New role of an age-old micronutrient in the management of periodontal disease in older adults. Geriatr. Gerontol. Int. 2015, 15, 241-254. [CrossRef] [PubMed]

2. Eke, P.I.; Dye, B.A.; Wei, L.; Thornton-Evans, G.O.; Genco, R.J. CDC Periodontal Disease Surveillance workgroup: James Beck (University of North Carolina, Chapel Hill, USA), Gordon Douglass (Past President, American Academy of Periodontology), Roy Page (University of Washin Prevalence of Periodontitis in adults in the United States: 2009 and 2010. J. Dent. Res. 2012, 91, 914-920. [CrossRef] [PubMed]

3. Zong, G.; Scott, A.E.; Griffiths, H.R.; Zock, P.L.; Dietrich, T.; Newson, R.S. Serum $\alpha$-tocopherol has a nonlinear inverse association with periodontitis among US adults. J. Nutr. 2015, 145, 893-899. [CrossRef] [PubMed]

4. Hasegawa, T.; Watase, H. Multiple risk factors of periodontal disease: A study of 9260 Japanese non-smokers. Geriatr. Gerontol. Int. 2004, 4, 37-43. [CrossRef]

5. Van der Velden, U.; Kuzmanova, D.; Chapple, I.L.C. Micronutritional approaches to periodontal therapy. J. Clin. Periodontol. 2011, 38, 142-158. [CrossRef] [PubMed]

6. Massaro, M.; Scoditti, E.; Carluccio, M.A.; De Caterina, R. Nutraceuticals and prevention of atherosclerosis: Focus on $\omega-3$ polyunsaturated fatty acids and Mediterranean diet polyphenols. Cardiovasc. Ther. 2010, 28, e13-e19. [CrossRef] [PubMed]

7. Chauhan, B.; Kumar, G.; Kalam, N.; Ansari, S.H. Current concepts and prospects of herbal nutraceutical: A review. J. Adv. Pharm. Technol. Res. 2013, 4, 4-8. [CrossRef] [PubMed]

8. Finley, J.W. The nutraceutical revolution: Emerging vision or broken dream? Understanding scientific and regulatory concerns. Clin. Res. Regul. Aff. 2016, 33, 1-3. [CrossRef]

9. Zeisel, S.H. Regulation of nutraceuticals. Science 1999, 285, 1853-1855. [CrossRef] [PubMed]

10. Gulati, O.P.; Berry Ottaway, P. Legislation relating to nutraceuticals in the European Union with a particular focus on botanical-sourced products. Toxicology 2006, 221, 75-87. [CrossRef] [PubMed]

11. Riley, J.H. Clinical pathology: Preanalytical variation in preclinical safety assessment studies-effect on predictive value of analyte tests. Toxicol. Pathol. 1992, 20, 490-500. [CrossRef] [PubMed]

12. Bascones-Martínez, A.; Figuero-Ruiz, E. Periodontal diseases as bacterial infection. Med. Oral Patol. Oral Cir. Bucal 2004, 9, 92-100. [CrossRef]

13. Nasri, H.; Baradaran, A.; Shirzad, H.; Rafieian-Kopaei, M. New concepts in nutraceuticals as alternative for pharmaceuticals. Int. J. Prev. Med. 2014, 5, 1487-1499. [PubMed]

14. Kaye, E.K. Nutrition, dietary guidelines and optimal periodontal health. Periodontology 2012, 58, 93-111. [CrossRef] [PubMed]

15. Quiles, J.L.; Varela-López, A. The role of nutrition in periodontal diseases. In Studies on Periodontal Disease; Springer: New York, NY, USA, 2014; pp. 251-278.

16. Varela-López, A.; Bullón, P.; Giampieri, F.; Quiles, J.L. Non-nutrient, naturally occurring phenolic compounds with antioxidant activity for the prevention and treatment of periodontal diseases. Antioxidants 2015, 4, 447-481. [CrossRef] [PubMed]

17. Varela-López, A.; Quiles, J.L.; Cordero, M.; Giampieri, F.; Bullón, P. Oxidative stress and dietary fat type in relation to periodontal disease. Antioxidants 2015, 4, 322-344. [CrossRef] [PubMed]

18. Varela-López, A.; Giampieri, F.; Bullón, P.; Battino, M.; Quiles, J.L. A systematic review on the implication of minerals in the onset, severity and treatment of periodontal disease. Molecules 2016, 21, 1183. [CrossRef] [PubMed]

19. Boushey, C.; Coulston, A.; Rock, C.; Monsen, E. Nutrition in the Prevention and Treatment of Disease; Academic Press: San Diego, CA, USA, 2001; ISBN 0-12-193155-2.

20. Mayne, S.T. Antioxidant nutrients and chronic disease: Use of biomarkers of exposure and oxidative stress status in epidemiologic research. J. Nutr. 2003, 133 (Suppl. 3), 933S-940S. [CrossRef] [PubMed]

21. Bikle, D.D. Vitamin D metabolism, mechanism of action, and clinical applications. Chem. Biol. 2014, 21, 319-329. [CrossRef] [PubMed] 
22. Fukumoto, S. Phosphate metabolism and vitamin D. Bonekey Rep. 2014, 3, 497. [CrossRef] [PubMed]

23. Gil, Á.; Plaza-Diaz, J.; Mesa, M.D. Vitamin D: Classic and novel actions. Ann. Nutr. Metab. 2018, 72, 87-95. [CrossRef] [PubMed]

24. Wacker, M.; Holick, M.F. Sunlight and vitamin D: A global perspective for health. Dermatoendocrinology 2013, 5, 51-108. [CrossRef] [PubMed]

25. Holick, M.F. Sunlight and vitamin D for bone health and prevention of autoimmune diseases, cancers, and cardiovascular disease. Am. J. Clin. Nutr. 2004, 80, 1678S-1688S. [CrossRef] [PubMed]

26. Adegboye, A.R.; Boucher, B.J.; Kongstad, J.; Fiehn, N.-E.; Christensen, L.B.; Heitmann, B.L. Calcium, vitamin D, casein and whey protein intakes and periodontitis among Danish adults. Public Health Nutr. 2016, 19, 503-510. [CrossRef] [PubMed]

27. Jimenez, M.; Giovannucci, E.; Krall Kaye, E.; Joshipura, K.J.; Dietrich, T. Predicted vitamin D status and incidence of tooth loss and periodontitis. Public Health Nutr. 2014, 17, 844-852. [CrossRef] [PubMed]

28. Dietrich, T.; Joshipura, K.J.; Dawson-Hughes, B.; Bischoff-Ferrari, H.A. Association between serum concentrations of 25-hydroxyvitamin D3 and periodontal disease in the US population. Am. J. Clin. Nutr. 2004, 80, 108-113. [CrossRef] [PubMed]

29. Abreu, O.J.; Tatakis, D.N.; Elias-Boneta, A.R.; López Del Valle, L.; Hernandez, R.; Pousa, M.S.; Palacios, C. Low vitamin D status strongly associated with periodontitis in Puerto Rican adults. BMC Oral Health 2016, 16, 89. [CrossRef] [PubMed]

30. Alshouibi, E.N.; Kaye, E.K.; Cabral, H.J.; Leone, C.W.; Garcia, R.I. Vitamin D and periodontal health in older men. J. Dent. Res. 2013, 92, 689-693. [CrossRef] [PubMed]

31. Lee, H.J.; Je, D.I.; Won, S.J.; Paik, D.I.; Bae, K.H. Association between vitamin D deficiency and periodontal status in current smokers. Community Dent. Oral Epidemiol. 2015, 43, 471-478. [CrossRef] [PubMed]

32. Millen, A.E.; Hovey, K.M.; LaMonte, M.J.; Swanson, M.; Andrews, C.A.; Kluczynski, M.A.; Genco, R.J.; Wactawski-Wende, J. Plasma 25-Hydroxyvitamin D concentrations and periodontal disease in postmenopausal women. J. Periodontol. 2013, 84, 1243-1256. [CrossRef] [PubMed]

33. Page, R.C.; Eke, P.I. Case definitions for use in population-based surveillance of periodontitis. J. Periodontol. 2007, 78, 1387-1399. [CrossRef] [PubMed]

34. Boggess, K.A.; Espinola, J.A.; Moss, K.; Beck, J.; Offenbacher, S.; Camargo Jr., C. A. Vitamin D status and periodontal disease among pregnant women. J. Periodontol. 2011, 82, 195-200. [CrossRef] [PubMed]

35. Liu, K.; Meng, H.; Tang, X.; Xu, L.; Zhang, L.; Chen, Z.; Shi, D.; Feng, X.; Lu, R. Elevated plasma calcifediol is associated with aggressive periodontitis. J. Periodontol. 2009, 80, 1114-1120. [CrossRef] [PubMed]

36. Freeland, J.H.; Cousins, R.J.; Schwartz, R. Relationship of mineral status and intake to periodontal disease. Am. J. Clin. Nutr. 1976, 29, 745-749. [CrossRef] [PubMed]

37. Petti, S.; Cairella, G.; Tarsitani, G. Nutritional variables related to gingival health in adolescent girls. Community Dent. Oral Epidemiol. 2000, 28, 407-413. [CrossRef] [PubMed]

38. Chapple, I.L.C.; Milward, M.R.; Dietrich, T. The prevalence of inflammatory periodontitis is negatively associated with serum antioxidant concentrations. J. Nutr. 2007, 137, 657-664. [CrossRef] [PubMed]

39. Waerhaug, J. Prevalence of periodontal disease in Ceylon. Association with age, sex, oral hygiene, socio-economic factors, vitamin deficiencies, malnutrition, betel and tobacco consumption and ethnic group. Final report. Acta Odontol. Scand. 1967, 25, 205-231. [CrossRef] [PubMed]

40. World Health Organization (WHO). Vitamin A deficiency and Xerophthalmia: Report of a Joint WHO/USAID Meeting; WHO: Yakarta, Indonesia, 1974.

41. Iwasaki, M.; Moynihan, P.; Manz, M.C.; Taylor, G.W.; Yoshihara, A.; Muramatsu, K.; Watanabe, R.; Miyazaki, H. Dietary antioxidants and periodontal disease in community-based older Japanese: A 2-year follow-up study. Public Health Nutr. 2013, 16, 330-338. [CrossRef] [PubMed]

42. Linden, G.J.; McClean, K.M.; Woodside, J.V.; Patterson, C.C.; Evans, A.; Young, I.S.; Kee, F. Antioxidants and periodontitis in 60-70-year-old men. J. Clin. Periodontol. 2009, 36, 843-849. [CrossRef] [PubMed]

43. Pino-Lagos, K.; Benson, M.J.; Noelle, R.J. Retinoic acid in the immune system. Ann. N. Y. Acad. Sci. 2008, 1143, 170-187. [CrossRef] [PubMed]

44. Olson, J.A. Provitamin A function of carotenoids: The conversion of beta-carotene into vitamin A. J. Nutr. 1989, 119, 105-108. [CrossRef] [PubMed]

45. Galano, A. Relative antioxidant efficiency of a large series of carotenoids in terms of one electron transfer reactions. J. Phys. Chem. B 2007, 111, 12898-12908. [CrossRef] [PubMed] 
46. Burton, G.W.; Ingold, K.U. Beta-Carotene: An unusual type of lipid antioxidant. Science 1984, 224, 569-573. [CrossRef] [PubMed]

47. Mathews-Roth, M.M.; Pathak, M.A.; Fitzpatrick, T.B.; Harber, L.H.; Kass, E.H. Beta carotene therapy for erythropoietic protoporphyria and other photosensitivity diseases. Arch. Dermatol. 1977, 113, 1229-1232. [CrossRef] [PubMed]

48. Urbach, C.; Hickman, K.; Harris, P.L. Effect of individual vitamins A, C, E, and carotene administered at high levels on their concentration in the blood. Exp. Med. Surg. 1952, 10, 7-20. [PubMed]

49. Kulkarni, V.; Bhatavadekar, N.B.; Uttamani, J.R. The effect of nutrition on periodontal disease: A systematic review. J. Calif. Dent. Assoc. 2014, 42, 302-311. [PubMed]

50. Neiva, R.F.; Steigenga, J.; Al-Shammari, K.F.; Wang, H.-L. Effects of specific nutrients on periodontal disease onset, progression and treatment. J. Clin. Periodontol. 2003, 30, 579-589. [CrossRef] [PubMed]

51. Hamasaki, T.; Kitamura, M.; Kawashita, Y.; Ando, Y.; Saito, T. Periodontal disease and percentage of calories from fat using national data. J. Periodontal Res. 2017, 52, 114-121. [CrossRef] [PubMed]

52. Pollack, S.V. Wound healing: A review. III. Nutritional factors affecting wound healing. J. Enteros. Ther. 1982, 9, 28-33. [CrossRef]

53. Lingström, P.; Fure, S.; Dinitzen, B.; Fritzne, C.; Klefbom, C.; Birkhed, D. The release of vitamin C from chewing gum and its effects on supragingival calculus formation. Eur. J. Oral Sci. 2005, 113, 20-27. [CrossRef] [PubMed]

54. Coven, E.M. Effect of prophylaxis and vitamin supplementation upon periodontal index in children. J. Periodontol. 1965, 36, 494-500. [CrossRef] [PubMed]

55. Abou Sulaiman, A.E.; Shehadeh, R.M.H. Assessment of total antioxidant capacity and the use of vitamin C in the treatment of non-smokers with chronic periodontitis. J. Periodontol. 2010, 81, 1547-1554. [CrossRef] [PubMed]

56. Glickman, I.; Dines, M.M. Effect of increased ascorbic acid blood levels on the ascorbic acid level in treated and non-treated gingiva. J. Dent. Res. 1963, 42, 1152-1158. [CrossRef] [PubMed]

57. Tomofuji, T.; Ekuni, D.; Sanbe, T.; Irie, K.; Azuma, T.; Maruyama, T.; Tamaki, N.; Murakami, J.; Kokeguchi, S.; Yamamoto, T. Effects of vitamin C intake on gingival oxidative stress in rat periodontitis. Free Radic. Biol. Med. 2009, 46, 163-168. [CrossRef] [PubMed]

58. Akman, S.; Canakci, V.; Kara, A.; Tozoglu, U.; Arabaci, T.; Dagsuyu, I.M. Therapeutic effects of alpha lipoic acid and vitamin $\mathrm{C}$ on alveolar bone resorption after experimental periodontitis in rats: A biochemical, histochemical, and stereologic study. J. Periodontol. 2013, 84, 666-674. [CrossRef] [PubMed]

59. Sanbe, T.; Tomofuji, T.; Ekuni, D.; Azuma, T.; Tamaki, N.; Yamamoto, T. Oral administration of vitamin C prevents alveolar bone resorption induced by high dietary cholesterol in rats. J. Periodontol. 2007, 78, 2165-2170. [CrossRef] [PubMed]

60. Miyajima, K.; Ito, R.; Matsuyama, T.; Togari, A.; Matsumoto, S.; Iizuka, T. Morphological differences in the skull of ascorbic acid-deficient ODS rats. Arch. Oral Biol. 1995, 40, 293-297. [CrossRef]

61. De Sousa Carvalho, R.; de Souza, C.M.; de Souza Neves, J.C.; Holanda-Pinto, S.A.; Pinto, L.M.S.; Brito, G.A.C.; de Andrade, G.M. Vitamin E does not prevent bone loss and induced anxiety in rats with ligature-induced periodontitis. Arch. Oral Biol. 2013, 58, 50-58. [CrossRef] [PubMed]

62. Cohen, M.E.; Meyer, D.M. Effect of dietary vitamin E supplementation and rotational stress on alveolar bone loss in rice rats. Arch. Oral Biol. 1993, 38, 601-606. [CrossRef]

63. Esaki, M.; Morita, M.; Akhter, R.; Akino, K.; Honda, O. Relationship between folic acid intake and gingival health in non-smoking adults in Japan. Oral Dis. 2010, 16, 96-101. [CrossRef] [PubMed]

64. Yu, Y.-H.; Kuo, H.-K.; Lai, Y.-L. The association between serum folate levels and periodontal disease in older adults: Data from the National Health and Nutrition Examination Survey 2001/02. J. Am. Geriatr. Soc. 2007, 55, 108-113. [CrossRef] [PubMed]

65. Nishida, M.; Grossi, S.G.; Dunford, R.G.; Ho, A.W.; Trevisan, M.; Genco, R.J. Calcium and the risk for periodontal disease. J. Periodontol. 2000, 71, 1057-1066. [CrossRef] [PubMed]

66. Benzie, I.F. Vitamin C: Prospective functional markers for defining optimal nutritional status. Proc. Nutr. Soc. 1999, 58, 469-476. [CrossRef] [PubMed]

67. Padh, H. Vitamin C: Newer insights into its biochemical functions. Nutr. Rev. 1991, 49, 65-70. [CrossRef] [PubMed] 
68. Rubinoff, A.B.; Latner, P.A.; Pasut, L.A. Vitamin C and oral health. J. Can. Dent. Assoc. 1989, 55, 705-707. [PubMed]

69. Nishida, M.; Grossi, S.G.; Dunford, R.G.; Ho, A.W.; Trevisan, M.; Genco, R.J. Dietary vitamin C and the risk for periodontal disease. J. Periodontol. 2000, 71, 1215-1223. [CrossRef] [PubMed]

70. Kuzmanova, D.; Jansen, I.D.C.; Schoenmaker, T.; Nazmi, K.; Teeuw, W.J.; Bizzarro, S.; Loos, B.G.; van der Velden, U. Vitamin C in plasma and leucocytes in relation to periodontitis. J. Clin. Periodontol. 2012, 39, 905-912. [CrossRef] [PubMed]

71. Amaliya, M.F.; Timmerman, M.F.; Abbas, F.; Loos, B.G.; Van der Weijden, G.A.; Van Winkelhoff, A.J.; Winkel, E.G.; Van der Velden, U. Java project on periodontal diseases: The relationship between vitamin C and the severity of periodontitis. J. Clin. Periodontol. 2007, 34, 299-304. [CrossRef] [PubMed]

72. Thomas, B.; Kumari, S.; Ramitha, K.; Ashwini Kumari, M.B. Comparative evaluation of micronutrient status in the serum of diabetes mellitus patients and healthy individuals with periodontitis. J. Indian Soc. Periodontol. 2010, 14, 46-49. [CrossRef] [PubMed]

73. Pussinen, P.J.; Laatikainen, T.; Alfthan, G.; Asikainen, S.; Jousilahti, P. Periodontitis is associated with a low concentration of vitamin C in plasma. Clin. Diagn. Lab. Immunol. 2003, 10, 897-902. [CrossRef] [PubMed]

74. Michaud, D.S.; Izard, J.; Rubin, Z.; Johansson, I.; Weiderpass, E.; Tjønneland, A.; Olsen, A.; Overvad, K.; Boutron-Ruault, M.C.; Clavel-Chapelon, F.; et al. Lifestyle, dietary factors, and antibody levels to oral bacteria in cancer-free participants of a European cohort study. Cancer Causes Control 2013, 24, 1901-1909. [CrossRef] [PubMed]

75. Iwasaki, M.; Manz, M.C.; Taylor, G.W.; Yoshihara, A.; Miyazaki, H. Relations of serum ascorbic acid and $\alpha$-tocopherol to periodontal disease. J. Dent. Res. 2012, 91, 167-172. [CrossRef] [PubMed]

76. Eklund, S.A.; Burt, B.A. Risk factors for total tooth loss in the United States; longitudinal analysis of national data. J. Public Health Dent. 1994, 54, 5-14. [CrossRef] [PubMed]

77. Amarasena, N.; Ogawa, H.; Yoshihara, A.; Hanada, N.; Miyazaki, H. Serum vitamin C-periodontal relationship in community-dwelling elderly Japanese. J. Clin. Periodontol. 2005, 32, 93-97. [CrossRef] [PubMed]

78. Varela-López, A.; Battino, M.; Bullón, P.; Quiles, J.L. Dietary antioxidants for chronic periodontitis prevention and its treatment. A review on current evidences from animal and human studies. Ars Pharm. 2015, 56, 131-140. [CrossRef]

79. Wong, R.S.Y.; Radhakrishnan, A.K. Tocotrienol research: Past into present. Nutr. Rev. 2012, 70, $483-490$. [CrossRef] [PubMed]

80. Traber, M.G.; Atkinson, J. Vitamin E, antioxidant and nothing more. Free Radic. Biol. Med. 2007, 43, 4-15. [CrossRef] [PubMed]

81. Agabegi, S.S.; Stern, P.J. Bias in research. Am. J. Orthop. (Belle Mead. NJ) 2008, 37, 242-248. [PubMed]

82. Vandenbroucke, J.P.; von Elm, E.; Altman, D.G.; Gøtzsche, P.C.; Mulrow, C.D.; Pocock, S.J.; Poole, C.; Schlesselman, J.J.; Egger, M.; STROBE Initiative. Strengthening the reporting of observational studies in epidemiology (STROBE): Explanation and elaboration. Int. J. Surg. 2014, 12, 1500-1524. [CrossRef] [PubMed]

83. Higgins, J.P.T.; Altman, D.G.; Gøtzsche, P.C.; Jüni, P.; Moher, D.; Oxman, A.D.; Savovic, J.; Schulz, K.F.; Weeks, L.; Sterne, J.A.C.; Cochrane Bias Methods Group; Cochrane Statistical Methods Group. The Cochrane Collaboration's tool for assessing risk of bias in randomised trials. BMJ 2011, 343, d5928. [CrossRef]

(C) 2018 by the authors. Licensee MDPI, Basel, Switzerland. This article is an open access article distributed under the terms and conditions of the Creative Commons Attribution (CC BY) license (http:/ / creativecommons.org/licenses/by/4.0/). 